\title{
Factors Affecting Electronic Word-of-Mouth on Social Networking Websites in Egypt - An Application of the Technology Acceptance Model
}

\author{
S. S. Doma ${ }^{1}$, N. A. Elaref ${ }^{2}$ and M. A. Abo Elnaga ${ }^{3}$ \\ 1,2,3 Faculty of Commerce, Alexandria University, Alexandria, Egypt
}

Correspondence should be addressed to: S. S. Doma; shyma.salah@yahoo.com

Received date: 23 March 2015; Accepted date: 30 July 2015; Published date: 28 December 2015

Academic Editor: Dina Rateb

Copyright @ 2015. S. S. Doma, N. A. Elaref and M. A. Abo Elnaga. Distributed under Creative Commons CC-BY 4.0

\begin{abstract}
The current paper attempts to investigate the consumers' actual usage behavior of electronic-word-of-mouth (eWOM) on social networking sites (SNS) and to develop a conceptual framework that could help increase the understanding of consumers' use of SNS as a vehicle for eWOM. Accordingly, we examined the factors affecting eWOM on SNS in the Egyptian environment using the technology acceptance model (TAM). A sample of 391 users was drawn from the Facebook users in Egypt. Data were analyzed using structural equation modeling (SEM). Findings indicate that social benefits, economic incentives, concern for others, extraversion and perceived usefulness are all factors that positively affect eWOM on SNS. Perceived ease of use had a positive effect on perceived usefulness of eWOM on SNS. However, perceived ease of use had a negative effect on the intention to use eWOM on SNS. Finally, the behavioral intention to use eWOM on SNS was found to affect the actual usage behavior of eWOM on SNS positively.
\end{abstract}

Keywords: Electronic word-of-mouth (eWOM), Social networking websites (SNS), Technology acceptance model (TAM), Structural equation modeling (SEM).

\section{Introduction}

Since their introduction, social networking websites (SNS) have attracted millions of users, many of whom have integrated these sites into their daily lives. Accordingly, SNS have been paid mounting attention from scholars and marketers as they attract a fast-growing number of consumers by enabling them to visualize and articulate their social network and engage in social interactions. According to Clemons (2009), using traditional push strategies such as advertising over SNS are no longer successful because the networkers perceive the social network space to be vendor free. Most of the current efforts are done by using traditional marketing approaches such as advertising and mass marketing, and this is disregarding the main asset of the SNS and its ability to build social networks of trust. 
Advertisements on SNS are now losing their viewers and their credibility worldwide. Users of SNS generally join these websites for fun and for social image not for business or for clicking advertisements. They are now savvier and they use advertisements' banner blocking programs (Kim Jeong, and Lee 2010).

The use of electronic word of mouth (eWOM) is the main strength of the social networks. However, while current research has focused on the outcomes of eWOM (e.g., sales), little is known about the factors influencing consumers' eWOM behavior in computer-mediated environments, particularly on SNS (Brown et al., 2007). Marketers become more interested in emanating the power of eWOM in building brands and developing brand loyalty programs. eWOM has undoubtedly been a powerful marketing force. The significance of information consumers obtain from interpersonal sources in influencing consumer decision making has been well recognized in marketing and consumer behavior literature (Engel, Kegerreis, and Blackwell, 1969; Gilly et al. 1998; Goldsmith and Clark 2008).

As more and more marketers attempt to harness the power of eWOM in SNS, rigorous investigation of the factors that lead to consumers' engagement in eWOM via the social networks is becoming critical (Goldsmith and Horowitz, 2006). SNS represent an ideal tool for eWOM, as consumers freely create and disseminate brand-related information in their established social networks composed of friends, classmates and other acquaintances (Jansen, Zhang, Sobel and Chowdury, 2009). They enable consumers to engage in some kind of social interactions by commenting, liking or passing along to their social connections. Through these interactions, consumers voluntarily display their brand preference along with their persona (e.g. name and picture), which can engender eWOM communication (Boyd and Ellison, 2007). Moreover, most SNS provide an opportunity for companies and brands to maintain a social network entity that can help the company keep ongoing social relationships with the social network users. Marketing in SNS should leverage these capabilities in order to maintain much more multidirectional communication between the companies and the network members (Clemons, 2009).

However, marketers lack the implications that can guide them towards a better understanding of eWOM on SNS and help them understand how to exert greater control over SNS users' sharing of eWOM in favor of the company's objectives. In other words, the lack of understanding for these factors and the inability to exert control over eWOM that is being shared over SNS especially negative eWOM, will probably lead to a higher threat to companies' success and reputation. According to literature, most previous studies have focused more on the impact of eWOM on company's performance, and only little research exists regarding the factors affecting eWOM especially on SNS. Hence, studying these factors could help academics narrow the gap in literature in a way that helps marketers improve their marketing efforts and CRM practices with their customers over SNS.

In the light of the above, the current paper attempts to investigate the factors that influence Egyptian consumers' eWOM behavior on SNS and to develop a conceptual framework that could help increase the understanding of their use of SNS as a vehicle for eWOM.

\section{Literature Review}

\section{WOM versus eWOM}

WOM communications have received extensive attention from both academics and practitioners for decades. Some research has reported WOM influence as greater than print advertisements, personal selling and radio advertising (Engel et al., 1969).

WOM is a consumer-dominated channel of marketing communication where the sender is independent of the market. It is therefore perceived to be more reliable, credible, and trustworthy by consumers compared to firm-initiated communications (Arndt, 1967). Traditional communications theory considers WOM as having a powerful influence on behavior, 
especially on consumers' information search, evaluation, and subsequent decision making. It provides information concerning product performance and the social and psychological consequences of the purchase decision (Boyd and Ellison, 2007).

WOM communication is bidirectional and interactive and is generally operated by two parties: opinion leaders and opinion seekers (Gilly et al., 1998). Conceptually, opinion leaders are the information generators or providers in WOM communications. Opinion leaders act as information transmitters who pass information from mass media on their peers and influence their opinions and choices often related to products or services (Feick and Price, 1987). In contrast, opinion seekers are those who desire to obtain information or opinions from others that help them evaluate products and services for their purchases (Flynn, Goldsmith, and Eastman, 1996).

An individual's tendency to influence attitude and overt behavior of others is typically termed as opinion leadership and is related to the individual's ability and motivation to share information (Flynn et al., 1996). Opinion seeking, on the other hand, is the behavioral counterpart to opinion leadership and occurs when an individual seeks advice and information from a friend, family member, or colleague who is often considered an opinion leader on the subject of interest (Goldsmith and Clark, 2008). In essence, opinion leadership and opinion seeking are two important aspects of information exchange which drive WOM communication in the domain of consumer behavior.

The emerging digital marketplace, with the Internet as a key facilitator, is an amorphous web of connections among producers and consumers. The Internet has also presented a synergistic opportunity for commentary, recommendation, suggestion, and referral through WOM. The emergence of eWOM has created both new possibilities and challenges for marketers. With the low cost in access and information exchange, eWOM sprouts in an unprecedented large scale, potentially creating new dynamics in the market (Dellarocas, 2003).
Hennig-Thurau, Gwinner, Walsh, and Gremler (2004) defined eWOM as "Any positive or negative statement made by potential, actual, or former customers about a product or company, which is made available to a multitude of people and institutions via the Internet". E-WOM can take place via many different online channels, consumers can post their opinions, comments and reviews of products on e-mails, discussion forums (e.g. zapak.com), instant messaging, weblogs (e.g. xanga.com), product review sites (e.g.,Amazon.com and Epinions.com), online communities, chat rooms, e-bulletin board systems, newsgroup and social networking sites (e.g. facebook.com) (Goldsmith, 2006; Gold smith and Horowitz, 2006).

Although eWOM was derived from traditional WOM as an extended information source via the Internet, eWOM differs from traditional WOM in several ways. The most obvious difference is that it is obtained online, while WOM is conducted through a face-to-face communication process, such as during meetings and telephone conversations. Online discussion forums, blogs, and emails are most often used for eWOM (Hoffman and Novak, 1996). The other important difference is that the information communicated by way of eWOM is often anonymous, unlike traditional WOM, which is usually communicated between people who know each other (Hoffman and Novak, 1996). Besides these differences, eWOM has higher accessibility than WOM, which means that millions of people can reach each other and share their information (Jeong and Jang, 2011).

Due to the ease of transmitting information online, eWOM has a faster diffusion effect than WOM. Contrary to traditional WOM, eWOM is measurable, since eWOM communication is conducted on the Internet, which can be helpful for researchers to trace and measure (Park and Kim, 2008). eWOM has the characteristics of a virtual communityanonymity, accessibility, and a diffusive effect. These characteristics provide consumers with a better opportunity and environment for social interactions. The 
advent of the Internet has extended consumers' options for gathering unbiased product information from other consumers and provides the opportunity for consumers to offer their own consumptionrelated advice by engaging in eWOM. Given the distinct characteristics of Internet communication (e.g., directed to multiple individuals, available to other consumers for an indefinite period of time, and anonymous nature), eWOM deserves the serious attention of marketing researchers and managers (Hennig-Thurau et al., 2004). The impact of eWOM on consumer behavior has been widely investigated to provide guidance to business managers in their decision making and development of marketing strategies (Rong, Vu, Law, and $\mathrm{Li}, 2011$ ). However, to date, very little attention has been paid to factors that influence an individual's intention to provide an online review (Picazo-Vela, Chou, Melcher, and Pearson, 2010).

\section{eWOM on SNS}

The history of SNS goes back to 1997 when the first recognizable social network site "SixDegrees.com" was launched. It allowed users to create profiles, list their Friends and surf the Friends' lists (Boyd and Ellison, 2007). Among the many new media, SNS such as Facebook, MySpace, Twitter and LinkedIn have recently become one of the most popular online communication channels and have attracted millions of Internet users across the globe (Boyd and Ellison, 2007; Lenhart and Madden, 2007). As Boyd and Ellison (2007) defined, "Social networking sites are web-based services that allow individuals to construct a public profile and articulate a list of their contacts with whom they share a social network".

SNS allow consumers to obtain unbiased product information, share their experiences with products and brands with members in their social networks, either close friends or remote acquaintances, at the same time offer them an opportunity to express their own consumption related advice (Patterson, 2011).Without geographic and time constraints, consumers can easily and quickly exchange product-related information and opinions with their personal contacts and have the potential to reach global audiences who share common interests in a product or brand. With the new applications on SNS, the way consumers make purchase decisions and interact with members of their social network has fundamentally changed (Hung and Li, 2007).

SNS offer several tools for marketers to reach their targeted customers; First, branded profile pages, like online brand communities, allow marketers to create specific pages where consumers can register as members and show their commitment to the brand. Second, social advertisements enhance consumer involvement by encouraging them to participate in activities such as passing along promotional messages to their friends, similar to eWOM based viral marketing. Lastly, drawing from the concept of customer-relationships management (CRM), Facebook tracks consumer purchase behavior, utilizes the information to identify valuable customers, and delivers relevant messages to them. These advertising mechanisms in networking platforms facilitate marketers' implementation of advertising campaigns in SNS (Boyd and Ellison, 2007). As a result, a growing number of marketers are turning to online social medium to promote their brands to the highly-engaged consumers.

With the rapid growth in the popularity of SNS, academic research has examined users' usage patterns, self-presentation strategies, motivations, and social relationships associated with this relatively new online communication medium and provided an initial understanding of the phenomenon. Thus, SNS can play a significant role in sharing and distributing product related information, and can serve as an influential vehicle for eWOM. Several studies in literature examined eWOM on SNS (Jiyoung, 2009; Kwon and Wen, 2010; Pookulangara and Koesler, 2011; ParraLopez et al., 2011; Al-Gahtani, 2011).

Facebook is a computer-mediated social networking system that has become one of the most popular means of communication worldwide. Launched in 2004, Facebook had an estimated 1.2 million users in 2006. Also, Facebook reported that its number of active monthly users reached 1.06 billion globally in December 2012 (Chang and Heo, 2014). Facebook is currently ranked 
as the fourth most popular website in the world (Patterson, 2011).

A constantly increasing use of the Internet can be easily spotted in Egyptian society as Egyptians constitute about $22 \%$ of total users in the Arab region (Abdelsalam, Reddick, Gamal, and Al-shaar, 2013). It can clearly be seen that Facebook is the most commonly used online SNS.

The number of Facebook users in Arab countries reached 55 million users (Social Bakers, 2014). Over the period 2001-2010, Egypt's international Internet bandwidth expanded steadily with an average annual growth rate of $105 \%$ and with an average annual growth rate of the Internet usage by $64 \%$ during the same period (Arab Social Media Report, 2011). It was found that $78 \%$ of Egypt's internet users are less than 34 years old and that the total number of Facebook users in Egypt has reached 16.5 million (Social Bakers, 2014).

To date, studies have not converged on a comprehensive list of the major motives underlying college students' use of Facebook, nor have researchers explored how motives influence associations between Facebook activities and college students' social adjustment. Previous studies have shown that motives for doing an activity moderate the association between psychosocial outcomes and participation in the activity (Yang and Brown, 2013).

Since Facebook is ranked as the fourth most popular website in the world and the number one SNS in most countries, in addition to the fact that the number of its Egyptian users has reached 16.5 million users lately, choosing Facebook for the application of this study seems appropriate.

\section{Research Model and Hypotheses}

With more than 700 citations to the original proposal for TAM, Davis' research (Davis, 1989) has been adapted and extended in many ways. The researcher chooses the TAM for studying the factors affecting consumers' usage behavior of eWOM on SNS because TAM is considerably less general than TRA, designed to apply only to computer usage behavior (Davis, 1989). Moreover, numerous empirical studies have found that TAM consistently explains a substantial proportion of the variance (typically about 40\%) in usage intentions and behavior, and that TAM compares favorably with alternative models such as the Theory of Reasoned Action (TRA) and the Theory of Planned Behavior (TPB) (Venkatesh and Davis, 2000). Overall, TAM is superior to TRA or the TPB in predicting information system user behavior (Ajzen, 1991). Thus, choosing the TAM for this study seems to be more appropriate than TRA or TPB.

The researcher chose four variables to represent the external variables for this study and they are: "social benefits of eWOM on SNS", "concern for others of eWOM on SNS", "economic incentives of eWOM on SNS" and "extraversion/ self enhancement of eWOM on SNS ". There are two main reasons to explain the researcher's choice for these variables specifically for this study. First, according to literature, SNS users' emotions as external variables (e.g. social identity, self enhancement and concern for others) were found to have a significant impact on the perceived usefulness and perceived ease of use (Lee, Xiong and Huc, 2011; Venkatesh and Davis, 2000). The second reason is that these external variables (i.e. social identity, self enhancement and concern for others) in addition to economic incentives have been proved to be the primary reasons consumers publish eWOM on opinion platforms (Hennig-Thurau et al., 2004).

Based on TAM's relationships and its main constructs, the actual use behavior of eWOM on SNS represents the dependent variable of this study. Perceived usefulness, perceived ease of use and the intention to use eWOM on SNS represent the mediating variables. Finally, concern for others, economic incentives, self enhancement and social benefits of eWOM on SNS; are the independent variables and they are the external variables of this study. The current paper follows the path relationships proposed by the final version of TAM (Davis, 1989). Fig.1 presents this study's research model, developed based on TAM. 


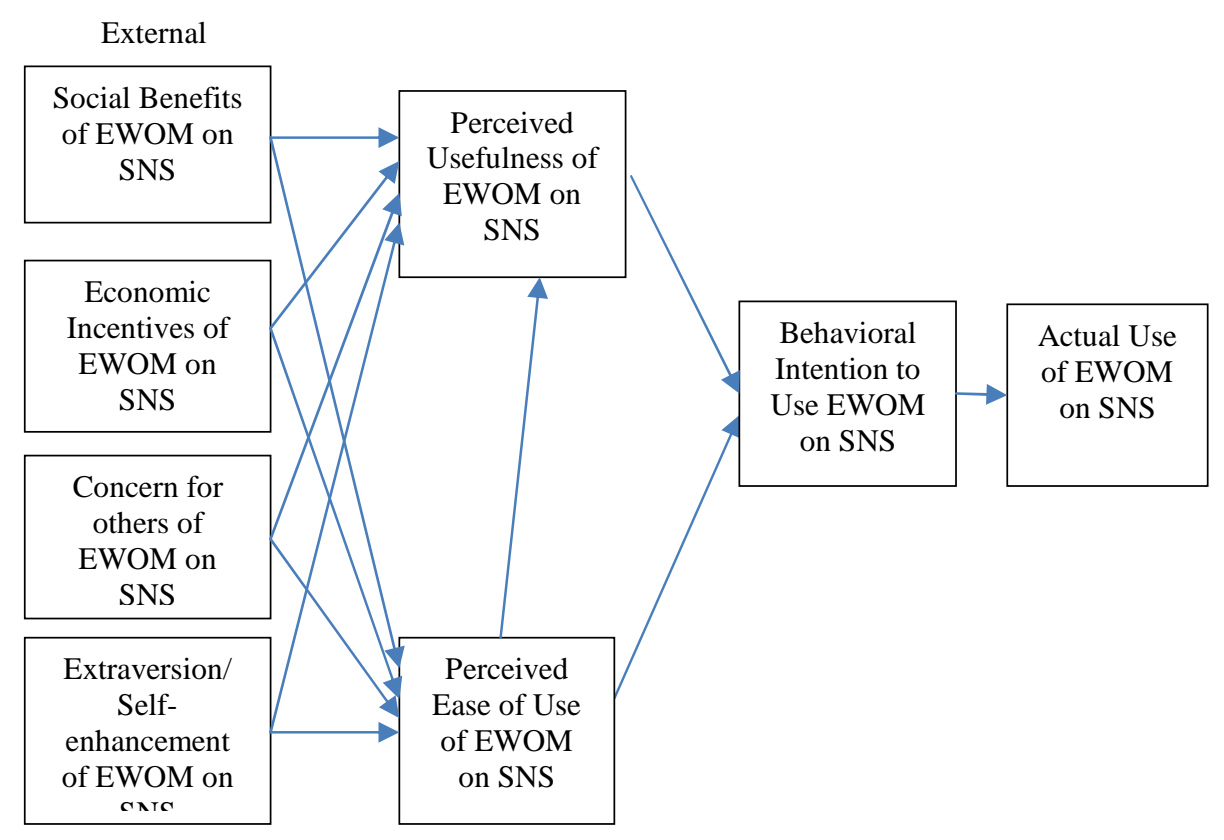

Figure1: The Research Framework

\section{Social Benefits}

Social benefits are defined as "Affiliation with a virtual community can represent a social benefit to a consumer for reasons of identification and social integration" (Hennig-Thurau et al., 2004); thus, it can be presumed that consumers engage in eWOM communication to participate in and belong to online communities (HennigThurau et al., 2004). According to TAM and the unified theory of acceptance and use of technology (UTAUT); Social influence and subjective norms affect perceived usefulness and usage behavior (Davis, 1989; Venkatesh and Davis, 2000; Venketash, Morris, Davis and Davis, 2003). Previous studies proved that social benefits have a positive direct relationship on perceived usefulness (Venkatesh and Davis, 2000; Venketash et al., 2003; Kwon and Wen, 2010; Lee, Xiong and Huc, 2011; Watjatrakul, 2013; Yap, Shen, Soetarto and Sweeney, 2012), also previous studies proved that social benefits have a positive direct relationship on perceived ease of use (Venkatesh and Davis, 2000; Venketash et al., 2003). Accordingly, the first hypothesis of this study will examine the effect of social benefits of eWOM on SNS on perceived usefulness and perceived ease of use of eWOM on SNS. Hence, this work proposes the following hypotheses:
H1 a: Social benefits of eWOM on SNS will have a positive effect on perceived usefulness of eWOM on SNS.

H1 b: Social benefits of eWOM on SNS will have a positive effect on perceived ease of use of eWOM on SNS.

\section{Economic Incentives}

Economic incentives refer to the utilization and integration of the social interaction within the virtual community to support profit oriented markets with formal exchange of goods, services and money. (Hennig-Thurau et al., 2004). Roumani, Nwankpa and Roumani (2014) suggested that economic incentives had a positive direct effect on perceived usefulness and perceived ease of use. Accordingly, economic incentives of eWOM on SNS will have a positive effect on perceived usefulness and perceived ease of use of eWOM on SNS. Thus, the second hypothesis will be formulated as follows:

H2 a: Economic Incentives of eWOM on SNS will have a positive effect on perceived usefulness of eWOM on SNS.

$\mathrm{H} 2 \mathrm{~b}$ : Economic Incentives of eWOM on SNS will have a positive effect on perceived ease of use of eWOM on SNS.

\section{Concern for Others}


Concern for others can be defined as "A genuine desire to help a friend or relative make a better purchase decision" (HennigThurau et al., 2004). E-WOM communication on Web-based opinion platforms may be initiated because of a desire to help other consumers with their buying decisions, to save others from negative experiences, or both. Thus, such communication can include both positive and negative consumer experiences with a product or company. This concern for others' motive is closely related to the concept of altruism (or prosocial behavior) intensively discussed in literature (Engel, Blackwell and Miniard, 1993; HennigThurau et al., 2004).

According to Kwon and Wen (2010), concern for others will have a positive effect on perceived usefulness. Also, ParraLopez (2011) found that concern for others had a positive effect on perceived ease of use. Therefore, in the current study concern for others of eWOM on SNS will have a positive effect on perceived usefulness and perceived ease of use eWOM on SNS. The third hypothesis will be formulated as follows:

H3 a: Concern for others of eWOM on SNS will have a positive effect on perceived usefulness of eWOM on SNS.

H3 b: Concern for others of eWOM on SNS will have a positive effect on perceived ease of use of eWOM on SNS.

\section{Extraversion / Self Enhancement}

Based on the WOM communication literature, two concrete motives that are associated with approval utility have been identified: self enhancement and economic rewards. The self enhancement motivation (Engel et al., 1993; Sundaram et al., 1998) is driven by one's desire for positive recognition from others. In the context of a Web-based opinion platform, this may take the form of being viewed as a consumption expert or intelligent shopper by other consumers. This motive refers to the existence of certain self-related consumer needs underlying behavior which can be gratified only through social interaction. Electronic communication that is read by others allows consumers to signal a kind of connoisseurship or a level of social status that can become important to one's self concept (Hennig-Thurau et al., 2004). Svendsen et al. (2013) found a positive direct effect of extraversion/ selfenhancement on perceived usefulness and perceived ease of use. Accordingly, the current study suggests that extraversion/ self-enhancement of eWOM on SNS will have a positive effect on perceived usefulness and perceived ease of use of eWOM on SNS. Therefore, the forth hypothesis will be as follows:

H4 a: Extraversion/ self-enhancement of eWOM on SNS will have a positive effect on perceived usefulness of eWOM on SNS.

H4 b: Extraversion/ self-enhancement of eWOM on SNS will have a positive effect on perceived ease of use of eWOM on SNS.

\section{Perceived Ease of Use and Perceived Ease of Use of eWOM on SNS}

Among the many variables that may influence system use, previous research suggests two determinants that are specifically important and they are perceived usefulness and perceived ease of use. First, perceived ease of use of eWOM on SNS would refer to the degree to which users expect that their participation in eWOM on SNS would be free of efforts. Several studies examined perceived ease of use in literature of eWOM and SNS (Lee et al., 2011; Jiyoung, 2009; Kwon and Wen, 2010; Jin, 2013). Second, people tend to use or not use an application to the extent they believe it will help them perform their tasks better and this is referred to as perceived usefulness (Davis, 1989). Several previous studies have examined the construct of perceived usefulness of eWOM on SNS (Casaló et al., 2010; Park and Lee, 2009; Jin 2013). According to TAM; upon which the current research model is built; perceived usefulness, perceived ease of use and intention to use eWOM on SNS are mediating variables between the actual usage behavior of eWOM on SNS (the dependent variable) and the external variables namely; concern for others, economic incentives, extraversion and social benefits; which are the independent variables of this study. TAM postulates that perceived ease of use has a positive direct effect on perceived usefulness (Davis, 
1989). Thus, the fifth hypothesis will be formulated as follows:

H5: Perceived ease of use of eWOM on SNS will have a positive effect on Perceived usefulness of eWOM on SNS. Also according to TAM, both perceived usefulness and perceived ease of use have a positive effect on behavioral intention. Hence, the sixth and seventh hypothesis will be:

H6: Perceived usefulness of eWOM on SNS will have a positive effect on behavioral intention to use eWOM on SNS.

H7: Perceived ease of use of eWOM on SNS will have a positive effect on behavioral intention to use eWOM on SNS.

\section{Intention to Use eWOM on SNS}

According to TAM, Intention to use eWOM on SNS is a mediating variable in this study. Several previous studies investigated the factors affecting intention to use eWOM. One of these studies belongs to Casaló et al. (2010) who attempted to explain consumers' intentions to participate in firm-hosted online travel communities, and other consumer behavioral intentions, on the basis of a model that integrates TPB, TAM, and Social Identity Theory. In addition, the research investigates the link between the intention to participate in a community and two behavioral intentions that may benefit the host firm: the intention to use the firm's products/services and the intention to recommend the host firm. Findings indicate that the intention to participate depends on the community characteristics (usefulness and ease of use), which help form more positive consumer attitudes. To boost participation, firms should promote the benefits of participating in these communities and thereby enable consumers to perceive the usefulness of participation. TAM path relationships demonstrate that behavioral intention has a positive effect on the actual use behavior. The eighth hypothesis will be as follows:

H8: Behavioral intention to use eWOM on SNS will have a positive effect on Actual use of eWOM on SNS.

\section{Actual Use Behavior of eWOM on SNS}

According to this study, usage behavior of eWOM on SNS is the dependent variable and the desired outcome of this study. Conceptually, eWOM on SNS can be examined through three aspects: opinion seeking, opinion giving and opinion passing (Flynn et al., 1996; Sun, Youn, Wu, and Kuntaraporn, 2006). Opinion leadership is commonly defined as a person's tendency to influence the purchase decisions of others (King and Summers, 1970). Flynn et al. (1996) suggest that "Opinion leadership happens when individuals try to influence the purchasing behavior of other consumers." Opinion seeking is the other related concept that plays a significant role in determining consumers' engagement in eWOM in SNS. In the traditional marketplace, opinion seeking is an important component of WOM communication because it can also facilitate the flow of information in the product diffusion process (Flynn et al., 1996; Goldsmith and Clark, 2008). Consumers with high levels of opinion seeking behavior, known as opinion seekers, tend to search for information and advice from others when making a purchase decision (Flynn et al., 1996).

Another important yet overlooked dimension of internet-based eWOM is online pass-along behavior (Norman and Russell, 2006; Sun et al., 2006). Because eWOM is defined as any positive or negative statement made by potential, actual, or former customers about a product or company, which is made available to a multitude of people and institutions via the Internet, pass-along behavior that can affect the flow of information should be considered as a component of such eWOM behavior. Furthermore, pass-along behavior is more likely to occur in an online context, as the unique characteristics of the Internet can facilitate information dissemination (Norman and Russell, 2006). By the same token, pass-along behavior is the natural component of eWOM occurring in SNS. In addition to giving or seeking information from friends or other contacts, pass-along behavior is a useful tool for SNS users to exchange information about a product or brand. 


\section{Research Methods}

\section{Data Collection and Sampling}

After a comprehensive review of the literature concerning the research variables, the researcher was able to define the research problem and hypotheses as well as designing a sampling plan. With respect to the sampling plan, the researcher gathered much information about the use of SNS in Egypt by scanning literature and reviewing online reports. In order to test the related hypotheses, a self administered survey was designed to collect the required information from the study elements. The designed selfadministered questionnaire consists of 5 pages, pre-developed measurement scales with satisfactory reliability for the eight main variables of the study, and finally questions about some demographics variables for purposes of respondents' description (A copy of the questionnaire is enclosed in Appendix 1).

A short introduction at the beginning of the questionnaire was presented to assure respondents of complete anonymity and to ensure their responses will be used for research purposes. The primary purpose of the study was described that the researcher attempts to find the factors affecting eWOM on SNS in Egypt. At the beginning of the questionnaire, the respondents were asked to rate their frequency of their use of Facebook by selecting one of the 5 ordinal possible options ranging from (more than two times per day) to (once a month). Moreover, the subjects were asked to select from 11 options of products which have the highest traffic over Facebook according to the most recent statistics published concerning Egyptian Facebook pages on Socialbakers.com (2014) as well as by asking a sample of 30 respondents prior to conducting the research about the products that has their highest number of their eWOM on Facebook. In addition to that, a twelfth open ended option was added to give the respondent the freedom of writing his own preference of the product which enjoys his highest engagement of eWOM behavior just in case none of the 11 options represents his eWOM activity on Facebook.
The questionnaire originates from predeveloped scales that are in English. Since the questionnaire should be distributed to Egyptian Facebook users, the researcher translated it into Arabic to ensure the full understanding of questionnaire items for all study elements. Moreover, some modifications to the wording of scales' items were necessary in order to meet the special use of SNS. After translation, the questionnaire was demonstrated to several academics in the field of business administration and marketing to ensure face validity of the measures. The academic community also judged the general structure of the questionnaire, and how clear and understandable are the items to be answered. After performing some modifications to the Arabic version of the questionnaire, it was handed out to an English proficient third party to translate it back to English. Compared with the original questionnaire, the English translated version demonstrated no major difference. All modifications took place and the final version of the Arabic questionnaire was ready for use.

To ensure convergent and discriminant validity of the scales, all of the research constructs were measured using existing validated scales. A five point Likert scale was used in this research. Respondents rate the extent to which they agree or disagree to each of the statements ranging from (1) strongly agree to (5) strongly disagree.

The population targeted in this study is all Egyptian users of SNS. Facebook was the chosen SNS for this study because it is the most popular SNS and accounts for $73 \%$ of SNS users (Carroll et al., 2012; Ellison et al., 2007; Kim Jeong, and Lee 2010; Lenhart et al., 2010). According to the Arab social media report (2012), the number of Facebook users in Egypt has reached $10,732,360$ users and according to Lenhart et al. (2010), 75\% of SNS users fall between the ages of $18-35$.

A non-probability convenience sampling technique was used in this study to gather primary data because no sampling frame with all Facebook users in Egypt was available for the researcher, so probability sampling technique could not be used. The researcher selected the city of Alexandria 
as one of the second biggest city in Egypt to represent the target population for this study. Targeting a sample size of 384 (Krejcie and Morgan, 1970), the researcher distributed 650 questionnaires yet 472 were received with a response rate of 72.61\%. Questionnaires were then scanned for completion and response patterns which resulted in 81 discarded questionnaires. Data were collected from a convenience sample of Alexandria's residents who use Facebook and the survey was completed using a self-administered questionnaire. Questionnaires were mainly eliminated if incomplete items are equal to or more than $10 \%$ of the total variable items (Malhotra and Bricks, 2003). This process resulted in 391 questionnaires ready for further analysis.

\section{Measurement Instrument}

According to Hennig-Thurau et al. (2004), four variables affect the use of eWOM; social benefits, concern for others, economic incentives and extraversion (self enhancement); and they represent the four independent variables of this study and their scales were adapted from HennigThurau et al. (2004).

According to TAM, perceived usefulness and perceived ease of use along with the intention to use are the mediating variables between independent variables and the dependent variable. Measurement for the mediating variables were adapted from Davis, Bagozzi, and Warshaw (1989) as for perceived usefulness and perceived ease of use; a 4 items scale with some wording modifications were adapted from Kwon and Wen (2010) in order to fit the specific context of the SNS.

Actual usage behavior of eWOM on SNS was measured through its three dimensions which are; online opinion leadership, online opinion seeking, and online opinion forwarding (Flynn et al., 1996; Sun et al., 2006).

At the end of the questionnaire, several personal demographic data were requested from the respondent. The researcher preferred to place them at the end to prevent initial non-response decisions. The name of the respondent was not requested to ensure anonymity. Other descriptive information about the respondent was requested such as age, gender, education and income level. All demographic variables were measured using close ended questions classified into possible ordinal options.

\section{Statistical Methods}

All data collected through questionnaires were entered into SPSS statistical package (PASW Statistics 18) for further analysis. Descriptive statistics were used to summarize the basic features of the sample studied and their mean responses about the different variables. To assess the psychometric properties of the measures used in the study, the researcher tested the construct and discriminant validity of the operationally defined variables by conducting a confirmatory factor analysis. Furthermore, Cronbach's coefficient alpha was calculated to test the internal consistency of the measures.

A structural equation model (SEM) was tested using AMOS software (Analysis of Moment Structures). The model was estimated using the maximum likelihood procedure. Correlation coefficients were used to measure the strength among the study main concepts (Hair, Bush and Ortinau, 2003). The Spearman's rank order correlation could be used to answer questions about the overall strength of relationships between study variables.

\section{Results}

\section{Respondents Characteristics}

The sample reflects that most respondents were males with a percentage of $56.3 \%$. The sample covers all age segments, $76.4 \%$ of the sample belongs to the age segment from 18 to 34 . Individuals with a monthly income less than 2000 L.E represent about $52.2 \%$ of the sample. As for the educational level of the respondents, the sample indicates that $61.6 \%$ of the respondents belong to the graduate level while $31.2 \%$ are post graduates, which means that a total of 92.8 of the sample are highly educated users and this might reflect the fact that SNS users are characterized as young and better educated individuals with 
Facebook (73\%) being the most popular SNS (Carroll et al., 2012; Ellison et al., 2007; Kim, Jeong, and Lee 2010; Lenhart et al., 2010). The majority of respondents were active users of Facebook since $63.4 \%$ of the sample revealed that they log in to Facebook more than two times per day. Regarding the type of product, the sample reflects that approximately $30 \%$ of respondents preferred "News and published media" followed by "Fashion products and offers" with a percentage of $16 \%$ approximately, followed by $12.5 \%$ for "Electronic products". Table 1 shows the detailed sample demographics.

Table 1: Demographic Characteristics of Respondents

\begin{tabular}{|c|c|c|c|}
\hline Characteristics & Categories & Frequency & Percentage \\
\hline \multirow[t]{5}{*}{ Age } & $<17$ & 14 & $3.6 \%$ \\
\hline & $18-24$ & 162 & $41.4 \%$ \\
\hline & $25-34$ & 137 & $35.0 \%$ \\
\hline & $35-44$ & 54 & $13.8 \%$ \\
\hline & $>45$ & 24 & $6.1 \%$ \\
\hline \multirow[t]{3}{*}{ Gender } & Male & 220 & $56.3 \%$ \\
\hline & Female & 168 & $43 \%$ \\
\hline & $\mathrm{N} / \mathrm{A}$ & 3 & $0.8 \%$ \\
\hline \multirow[t]{4}{*}{ Educational Level } & Secondary & 27 & $6.9 \%$ \\
\hline & Graduate & 241 & $61.6 \%$ \\
\hline & Post Graduate & 122 & $31.2 \%$ \\
\hline & $\mathrm{N} / \mathrm{A}$ & 1 & $0.3 \%$ \\
\hline \multirow[t]{6}{*}{$\begin{array}{l}\text { Monthly Income } \\
\text { (L.E) }\end{array}$} & $<2000$ & 204 & $52.2 \%$ \\
\hline & $\begin{array}{l}2000-2999 \\
\text { L.E }\end{array}$ & 79 & $20.2 \%$ \\
\hline & $\begin{array}{l}3000-3999 \\
\text { L.E }\end{array}$ & 31 & $7.9 \%$ \\
\hline & $\begin{array}{l}4000-4999 \\
\text { L.E }\end{array}$ & 31 & $7.9 \%$ \\
\hline & > 5000 L.E & 35 & $9 \%$ \\
\hline & $\mathrm{N} / \mathrm{A}$ & 11 & $2.8 \%$ \\
\hline
\end{tabular}


Table 2: Frequency of Facebook Usage and Preferred Type of Product

\begin{tabular}{|c|c|c|c|}
\hline Characteristics & Categories & Frequency & Percentage \\
\hline \multirow{5}{*}{$\begin{array}{l}\text { Frequency of } \\
\text { Facebook } \\
\text { Usage }\end{array}$} & $>2$ times / Day & 248 & $63.4 \%$ \\
\hline & Two Times/ Day & 38 & $9.7 \%$ \\
\hline & Once/ Day & 50 & $12.8 \%$ \\
\hline & Once/Week & 41 & $10.5 \%$ \\
\hline & Once/ Month & 14 & $3.6 \%$ \\
\hline \multirow[t]{12}{*}{$\begin{array}{l}\text { Preferred Type } \\
\text { of Product }\end{array}$} & Electronic products & 49 & $12.5 \%$ \\
\hline & $\begin{array}{l}\text { Telecommunicatio } \\
\text { n offers }\end{array}$ & 19 & $4.9 \%$ \\
\hline & $\begin{array}{l}\text { News and } \\
\text { published media }\end{array}$ & 117 & $29.9 \%$ \\
\hline & $\begin{array}{l}\text { TV channels and } \\
\text { programs }\end{array}$ & 13 & $3.3 \%$ \\
\hline & Movies and Music & 17 & $4.3 \%$ \\
\hline & Fashion & 62 & $15.9 \%$ \\
\hline & Sports & 39 & $10 \%$ \\
\hline & Travel Offers & 23 & $5.9 \%$ \\
\hline & Food products & 3 & $0.8 \%$ \\
\hline & $\begin{array}{l}\text { Restaurants and } \\
\text { Cafes }\end{array}$ & 9 & 2.3 \\
\hline & Cars & 9 & 2.3 \\
\hline & Others & 31 & 7.9 \\
\hline
\end{tabular}

\section{Validity and Reliability of the Measurement Scales}

All measurement scales used in this research were subject to validity and reliability tests. Reliability measures the internal consistency of the construct's items (observed variables or factors) forming the unobserved variable (Hair et al., 1998; Sekaran and Bougie, 2003). Cronbach alpha was used to assess reliability. Validity is the extent to which an instrument measures what is supposed to measure correctly (Hair et al., 1998; Sekaran and Bougie, 2003).

First, face validity was conducted. The scales subject to the research were extracted from previous literature that tested their validity in different countries and were examined and validated by expert academics in the faculty of commerce, Alexandria University, business administration department, including marketing experts and other specialties. Second, construct validity was evaluated. Convergent and discriminant validity are the two subtypes of validity that make up construct validity. The factorial validity that tests the data using factor analysis (multivariate technique) ensures whether or not the theorized dimensions are applicable (Sekaran and Bougie, 2003).

The researcher used two factors' analysis; exploratory factor analysis (EFA) and confirmatory factor analysis (CFA), for reflective and formative variables. In order to perform an exploratory factor analysis (EFA), the average value extracted (AVE) for each variable component was calculated. Also, Kaiser-Meyer-Olkin (KMO) and Bartlett's test of sphericity were used to examine the adequacy of factor analysis. Bartlett test of sphericity provides the statistical probability that the correlation 
matrix has significant correlations among at least some of the variables. The larger the sample size, the more the sensitive Bartlett test is to detecting correlations among variables (Hair et al., 1998). Eigen Value was also calculated.

The researcher used factor analysis relying on the principal component analysis (PCA) to examine convergent validity. The Orthogonal rotation method or varimax for factor loading was used to ensure clearer differentiation. Table 3 shows the Eigen value, AVE, KMO, Bartlett test, and factor loading of the formative variables in the current study. The KMO results are all acceptable and significant for the Bartlett test at 0.00 levels. AVE values are all more than 50\%. Factor Loadings were all above the acceptable level which is 0.3 and all Eigen values were more than 1 (Hair et al., 1998).

Table 3: Statistics of Construct Items

\begin{tabular}{|c|c|c|c|c|c|}
\hline Variables & $\begin{array}{l}\text { Eigen } \\
\text { Values }\end{array}$ & AVE\% & $\begin{array}{l}\text { KMO*Bartlett } \\
\text { Sig. }\end{array}$ & $\begin{array}{l}\text { Factor } \\
\text { Loading }\end{array}$ & Alpha \\
\hline $\begin{array}{l}\text { Social } \\
\text { Benefits }\end{array}$ & 2.006 & $66.8 \%$ & $0.693^{*}$ & & 0.752 \\
\hline SB 1. & & & & 0.724 & \\
\hline SB 2. & & & & 0.711 & \\
\hline SB 3. & & & & 0.693 & \\
\hline $\begin{array}{l}\text { Economic } \\
\text { Incentives }\end{array}$ & 1.603 & $80.1 \%$ & $0.5^{*}$ & & 0.744 \\
\hline EI 1. & & & & 0.776 & \\
\hline EI 2. & & & & 0.776 & \\
\hline $\begin{array}{l}\text { Concern for } \\
\text { Others }\end{array}$ & 2.446 & $61.1 \%$ & $0.776^{*}$ & & 0.783 \\
\hline CFO 1. & & & & 0.768 & \\
\hline CFO 2. & & & & 0.755 & \\
\hline CFO 3. & & & & 0.632 & \\
\hline CFO 4. & & & & 0.622 & \\
\hline Extraversion & 2.693 & $67.3 \%$ & $0.807^{*}$ & & 0.835 \\
\hline Ext 1. & & & & 0.808 & \\
\hline Ext 2. & & & & 0.807 & \\
\hline Ext 3. & & & & 0.780 & \\
\hline Ext 4. & & & & 0.608 & \\
\hline $\begin{array}{l}\text { Perceived } \\
\text { Usefulness }\end{array}$ & 2.088 & $52.1 \%$ & $0.718^{*}$ & & 0.686 \\
\hline PU 1. & & & & 0.685 & \\
\hline PU 2. & & & & 0.636 & \\
\hline PU 3. & & & & 0.566 & \\
\hline PU 4. & & & & 0.521 & \\
\hline $\begin{array}{l}\text { Perceived } \\
\text { Ease of Use }\end{array}$ & 2.409 & $60.2 \%$ & $0.752^{*}$ & & 0.739 \\
\hline PEOU 1. & & & & 0.842 & \\
\hline PEOU 2. & & & & 0.774 & \\
\hline PEOU 3. & & & & 0.767 & \\
\hline PEOU 4. & & & & 0.332 & \\
\hline
\end{tabular}


Table 3: Statistics of Construct Items

\begin{tabular}{|c|c|c|c|c|c|}
\hline $\begin{array}{l}\text { Intention to } \\
\text { Use }\end{array}$ & 1.566 & $78.3 \%$ & $0.5^{*}$ & & 0.724 \\
\hline I 1. & & & & 0.752 & \\
\hline I 2. & & & & 0.752 & \\
\hline $\begin{array}{l}\text { Online } \\
\text { Opinion } \\
\text { Leadership }\end{array}$ & 4.527 & $56.5 \%$ & $0.906^{*}$ & & 0.889 \\
\hline OL 1. & & & & 0.818 & \\
\hline OL 2. & & & & 0.816 & \\
\hline OL 3. & & & & 0.735 & \\
\hline OL 4. & & & & 0.705 & \\
\hline OL 5. & & & & 0.695 & \\
\hline OL 6. & & & & 0.661 & \\
\hline OL 7. & & & & 0.629 & \\
\hline OL 8. & & & & 0.605 & \\
\hline $\begin{array}{l}\text { Online } \\
\text { Opinion } \\
\text { Seeking }\end{array}$ & 4.336 & $54.2 \%$ & 0.898* & & 0.876 \\
\hline OS 1. & & & & 0.741 & \\
\hline OS 2. & & & & 0.740 & \\
\hline OS 3. & & & & 0.739 & \\
\hline OS 4. & & & & 0.731 & \\
\hline OS 5. & & & & 0.707 & \\
\hline OS 6. & & & & 0.672 & \\
\hline OS 7. & & & & 0.622 & \\
\hline OS 8. & & & & 0.559 & \\
\hline $\begin{array}{l}\text { Online } \\
\text { Opinion } \\
\text { Forwarding }\end{array}$ & 3.314 & $55.2 \%$ & $0.864^{*}$ & & 0.834 \\
\hline OF 1. & & & & 0.827 & \\
\hline OF 2. & & & & 0.760 & \\
\hline OF 3. & & & & 0.699 & \\
\hline OF 4. & & & & 0.679 & \\
\hline OF 5. & & & & 0.556 & \\
\hline OF 6. & & & & 0.544 & \\
\hline
\end{tabular}


The researcher executed CFA through Amos 18 program and maximum likelihood
(ML) approach. Table 4 illustrates the results of the CFA.

Table 4: Results of the CFA

\begin{tabular}{|c|c|c|c|c|c|}
\hline Variables & Estimates & Variables & Estimates & Variables & Estimates \\
\hline $\begin{array}{l}\text { Extraversio } \\
\mathrm{n}\end{array}$ & & $\begin{array}{l}\text { Social } \\
\text { Benefit }\end{array}$ & & $\begin{array}{l}\text { Perceived } \\
\text { Usefulness } \\
\end{array}$ & \\
\hline Ext4 & 0.850 & SB3 & 0.774 & PU1 & 0.443 \\
\hline Ext3 & 0.807 & SB2 & 0.737 & PU2 & 0.624 \\
\hline Ext2 & 0.793 & SB1 & 0.688 & PU3 & 0.309 \\
\hline Ext1 & 0.676 & & & PU4 & 0.399 \\
\hline $\begin{array}{l}\text { Concern } \\
\text { for Others }\end{array}$ & & $\begin{array}{l}\text { Perceived } \\
\text { Ease of } \\
\text { Use }\end{array}$ & & $\begin{array}{l}\text { Intention } \\
\text { to Use }\end{array}$ & \\
\hline CFO4 & 0.815 & PEOU1 & 0.407 & I1 & 0.688 \\
\hline CFO3 & 0.724 & PEOU2 & 0.446 & $\mathrm{I} 2$ & 0.753 \\
\hline CFO2 & 0.645 & PEOU3 & 0.449 & & \\
\hline CF01 & 0.674 & PEOU4 & 0.428 & & \\
\hline \multicolumn{6}{|l|}{$\begin{array}{l}\text { Economic } \\
\text { Incentives } \\
\end{array}$} \\
\hline EI2 & 0.660 & & & & \\
\hline EI1 & 0.788 & & & & \\
\hline \multicolumn{6}{|l|}{ eWOM } \\
\hline $\begin{array}{l}\text { Online } \\
\text { Opinion } \\
\text { Leadership }\end{array}$ & & $\begin{array}{l}\text { Online } \\
\text { Opinion } \\
\text { Seeking }\end{array}$ & & $\begin{array}{l}\text { Online } \\
\text { Opinion } \\
\text { Forwardin } \\
\text { g }\end{array}$ & \\
\hline OL1 & 0.690 & OS1 & 0.553 & OF1 & 0.587 \\
\hline OL 2 & 0.690 & OS 2 & 0.601 & OF 2 & 0.603 \\
\hline OL 3 & 0.700 & OS 3 & 0.563 & OF 3 & 0.701 \\
\hline OL 4 & 0.786 & OS 4 & 0.673 & OF 4 & 0.752 \\
\hline OL 5 & 0.712 & OS 5 & 0.650 & OF5 & 0.703 \\
\hline OL 6 & 0.689 & OS 6 & 0.658 & OF6 & 0.652 \\
\hline OL 7 & 0.562 & OS 7 & 0.698 & & \\
\hline OL 8 & 0.788 & OS 8 & 0.702 & & \\
\hline
\end{tabular}

As table 4 demonstrated, factor items were selected by grouping those items with the highest loadings (all above 0.30) on each given factor and that maximizes at the same time coefficient alpha reliability to ensure internal consistency of the separate factors. Table 5 shows that all variables have discriminant validity as all correlations are lower than reliability values. 
Table 5: Pearson's Correlation Matrix of all Research Variables Combined and Cronbach Alpha Coefficient for Each Variable

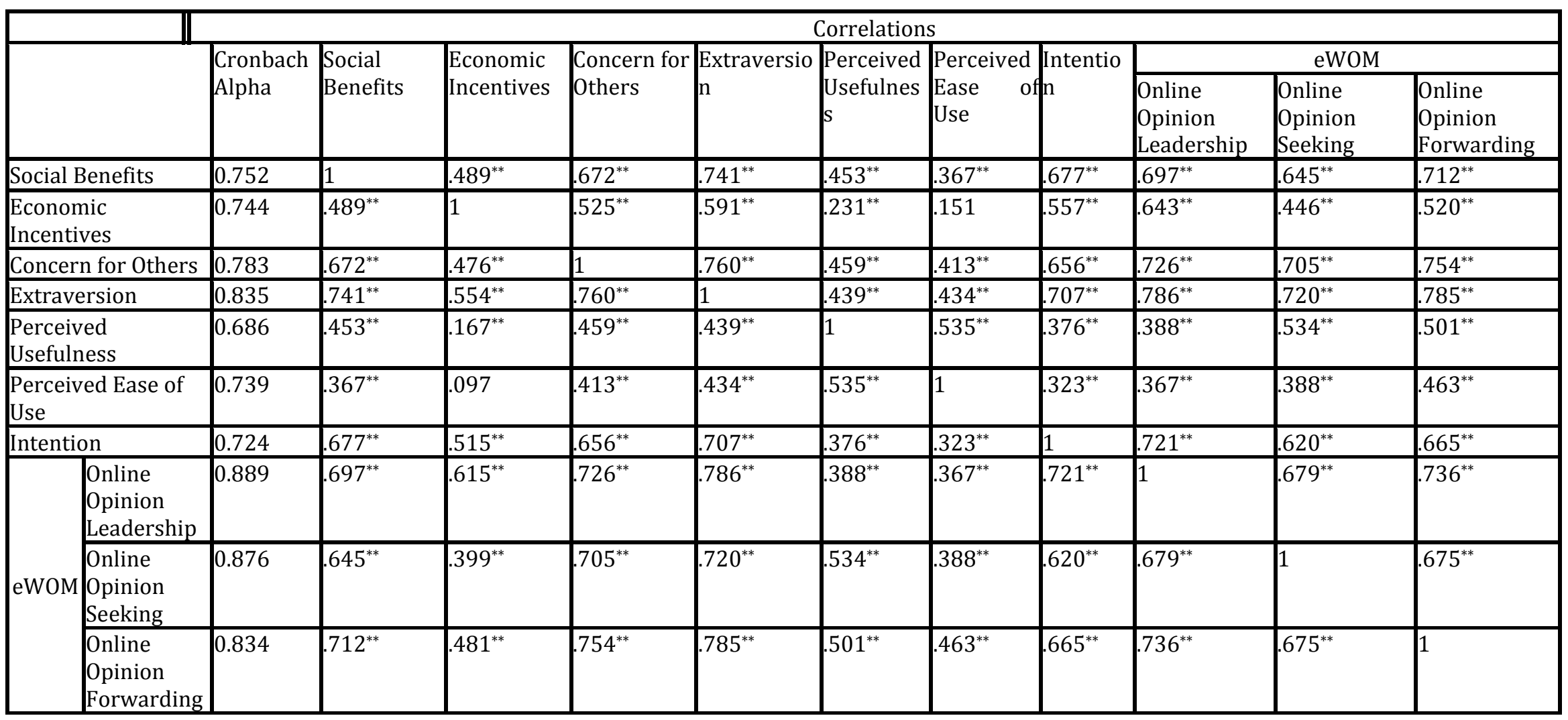

${ }^{* *}$ Correlation is significant at the 0.01 level (2-tailed). 


\section{Structural Model}

The researcher evaluated the research model fit indices using structural equation modeling (SEM). Table 6 represents the fit indices of the research model and figure 1 illustrates the standardized estimates of the research model using SEM.

Table 6: Some Fit Measures of the Overall Structured Model

\begin{tabular}{|c|c|c|}
\hline Goodness-of-fit Measures & Model Results & Recommended Value* \\
\hline Goodness of fit index (GFI) & $\begin{array}{l}937 \\
(0.000) \\
\end{array}$ & $\geq 0.9$ \\
\hline Root mean square residual (RMR) & 0.048 & $\leq 0.09$ \\
\hline $\begin{array}{l}\text { Root mean square error of } \\
\text { approximation (RMSEA) }\end{array}$ & 0.050 & $\leq 0.08$ \\
\hline \multicolumn{3}{|l|}{ Incremental fit measures } \\
\hline Adjusted goodness-of-fit index (AGFI) & 0.902 & $\geq 0.8$ \\
\hline Normed fit index (NFI) & 0.939 & $\geq 0.9$ \\
\hline Tucker - Lewis index (TLI) & 0.953 & $\geq 0.9$ \\
\hline Relative fit index (RFI) & 0.916 & $\geq 0.9$ \\
\hline Incremental fit index (IFI) & 0.966 & $\geq 0.9$ \\
\hline Comparative fit index (CFI) & 0.959 & $\geq 0.9$ \\
\hline \multicolumn{3}{|l|}{ Parsimonious fit measures } \\
\hline Normed Chi-square (CMIN/ DF) & 2.189 & $\leq 3$ \\
\hline $\begin{array}{l}\text { Parsimonious goodness- of-fit index } \\
(\text { PGFI) }\end{array}$ & 0.606 & $\begin{array}{l}\text { It ranges from } 0 \text { (poor } \\
\text { fit) to } 1 \text { (perfect fit). A } \\
\text { higher value indicates } \\
\text { better fit. }\end{array}$ \\
\hline
\end{tabular}

*Recommended values have been adapted from Hair et al. (1998)

The fit indices of the model that are shown above in table 6 indicate that the model possesses a very good fit. The squared multiple correlations in SEM for each dependant variable resemble the $\mathrm{R}$ square of regression analysis (Hair et al., 1998).
Table 7 possesses the squared multiple correlations values for all endogenous variables in the model.

\section{Table 7: Squared Multiple Correlations}

\begin{tabular}{|l|l|}
\hline Variables & Estimates \\
\hline Perceived Ease of Use & 0.124 \\
\hline Perceived Usefulness & 0.993 \\
\hline Intention to Use & 0.923 \\
\hline Actual use of eWOM & 0.996 \\
\hline
\end{tabular}

Accordingly, the model gives a good interpretation particularly for the dependent variable (Actual use of eWOM) which changes considering the variables 
and the relations among them by 0.996 . On the other hand, the model gives a poor interpretation of perceived ease of use (0.124) relative to other variables (Table 7).

\section{Results of Hypotheses Testing}

Table 8 includes results of unstandardized estimates (Unstand.). Standardized estimates (Stand.), standard error (SE), critical ratio (CR), and P-value of the direct relationships. The researcher assumed a confidence level of 0.95 . Thus, a P-value of up to 0.05 was accepted and any value above that level was rejected. The critical ratio (CR), which operates as a z-statistic of estimate different from zero, should have an absolute value greater or equal to 1.96 for a significant level of 0.05 or less (Hair et al., 1998).

Table 8: Regression Weights (Standardized and Unstandardized Estimates)

\begin{tabular}{|l|l|l|l|l|l|l|l|}
\hline $\begin{array}{l}\text { Dependent } \\
\text { Variables }\end{array}$ & & $\begin{array}{l}\text { Independe } \\
\text { nt } \\
\text { Variables }\end{array}$ & $\begin{array}{l}\text { Unstand. } \\
\text { Estimate }\end{array}$ & $\begin{array}{l}\text { Stand. } \\
\text { Estimate }\end{array}$ & S.E. & C.R. & P \\
\hline $\begin{array}{l}\text { Perceived } \\
\text { Ease of Use }\end{array}$ & $<---$ & $\begin{array}{l}\text { Concern } \\
\text { for Others }\end{array}$ & .210 & .243 & .071 & 2.963 & .003 \\
\hline $\begin{array}{l}\text { Perceived } \\
\text { Ease of Use }\end{array}$ & $<---$ & $\begin{array}{l}\text { Extraversi } \\
\text { on }\end{array}$ & .188 & .229 & .076 & 2.463 & .014 \\
\hline $\begin{array}{l}\text { Perceived } \\
\text { Ease of Use }\end{array}$ & $<---$ & $\begin{array}{l}\text { Social } \\
\text { Benefits }\end{array}$ & -.009 & -.010 & .065 & -.133 & .894 \\
\hline $\begin{array}{l}\text { Perceived } \\
\text { Ease of Use }\end{array}$ & $<---$ & $\begin{array}{l}\text { Economic } \\
\text { Incentives }\end{array}$ & -.169 & -.226 & .048 & -3.509 & $* * *$ \\
\hline $\begin{array}{l}\text { Perceived } \\
\text { Usefulness }\end{array}$ & $<---$ & $\begin{array}{l}\text { Social } \\
\text { Benefits }\end{array}$ & .041 & .111 & .013 & 3.150 & .002 \\
\hline $\begin{array}{l}\text { Perceived } \\
\text { Usefulness }\end{array}$ & $<---$ & $\begin{array}{l}\text { Perceived } \\
\text { Ease of Use }\end{array}$ & .363 & .816 & .145 & 2.512 & .012 \\
\hline $\begin{array}{l}\text { Perceived } \\
\text { Usefulness }\end{array}$ & $<---$ & $\begin{array}{l}\text { Economic } \\
\text { Incentives }\end{array}$ & .023 & .071 & .008 & 3.081 & .002 \\
\hline $\begin{array}{l}\text { Perceived } \\
\text { Usefulness }\end{array}$ & $<---$ & $\begin{array}{l}\text { Concern } \\
\text { for Others }\end{array}$ & .042 & .109 & .014 & 2.958 & .003 \\
\hline $\begin{array}{l}\text { Perceived } \\
\text { Usefulness }\end{array}$ & $<---$ & $\begin{array}{l}\text { Extraversi } \\
\text { on }\end{array}$ & .061 & .168 & .019 & 3.187 & .001 \\
\hline $\begin{array}{l}\text { Intentions } \\
\text { Usefulness }\end{array}$ & $<---$ & 5.032 & 2.339 & 1.467 & 3.430 & $* * *$ \\
\hline $\begin{array}{l}\text { Intentions } \\
\text { Easceived }\end{array}$ & $<---$ & -1.801 & -1.881 & 1.130 & -1.593 & .111 \\
\hline Actual use of & $<---$ & Intentions & .975 & .998 & .086 & 11.360 & $* * *$ \\
\hline
\end{tabular}

SEM revealed that concern for others, social benefits, economic incentives, extraversion of eWOM on SNS are significantly related to perceived usefulness of eWOM on SNS (CR values are greater than 1.96 and p-values are less than 0.05). Consequently, the study accepted $\mathrm{H} 1 \mathrm{a}$ and $\mathrm{H} 2 \mathrm{a}, \mathrm{H} 3 \mathrm{a}$ and $\mathrm{H} 4 \mathrm{a}$. On the other hand, social benefits are insignificantly related to perceived ease of use of eWOM on SNS (CR value is less than 1.96 and p-value is more than 0.05). Thus the study rejects $\mathrm{H} 1 \mathrm{~b}$. In addition, economic incentives of eWOM on SNS were found to have a significant negative relationship with perceived ease of use which contradicts the research hypothesis that suggested that economic incentives of eWOM on SNS have a direct positive relationship to perceived ease of use. Therefore, the study rejects $\mathrm{H} 2 \mathrm{~b}$. Concern For others and Extraversion of eWOM on SNS were significantly related to perceived ease of use of eWOM on SNS (CR values are 
greater than 1.96 and p-values are less than 0.05). Thus the study supports $\mathrm{H} 3 \mathrm{~b}$ and $\mathrm{H} 4 \mathrm{~b}$.

Moreover, the results showed that a perceived ease of use of eWOM on SNS had a significant relation with perceived usefulness of eWOM on SNS as it possesses a CR value greater than 1.96 and a p-value less than 0.05. Accordingly, the study supported $\mathrm{H} 5$. The results also indicate that perceived usefulness of eWOM on SNS holds a significant direct positive relationship with intention to use eWOM on SNS, CR value greater than 1.96 and a pvalue less than 0.05 . Therefore, the current study supported H6.
Furthermore, the results indicate that perceived ease of use of eWOM on SNS has an insignificant negative relationship with intention which contradicts the research hypothesis that suggested that perceived ease of use has a direct positive relationship to the intention to use eWOM on SNS, Therefore, the study rejects H7.

Finally, the results show a significant direct positive relationship between intention to use eWOM on SNS and actual use of eWOM with estimate value of 0.975 , CR value of 11.360 and a significant $P$ value. Therefore, H8 was supported. Table 9 summarizes what the researcher has accepted or rejected from the hypothesized relationships among variables.

Table 9: Summary of the Research Hypotheses

\begin{tabular}{|l|l|l|l|}
\hline \multicolumn{2}{|l|}{ Relationship Examined } & Results \\
\hline $\begin{array}{l}\text { H1 Social Benefits will have a positive effect on perceived } \\
\text { usefulness and perceived ease of use }\end{array}$ & Partially \\
\hline a) Social benefits & $\rightarrow$ & Perceived usefulness & Accepted \\
\hline b) Social benefits & $\rightarrow$ & Perceived ease of use & Rejected \\
\hline $\begin{array}{l}\text { H2) Economic Incentives will have a positive effect on perceived } \\
\text { usefulness and perceived ease of use }\end{array}$ & Partially \\
\hline a) Economic Incentives & $\rightarrow$ & Perceived usefulness & Accepted \\
\hline b) Economic Incentives & $\rightarrow$ & Perceived ease of use & Rejected \\
\hline $\begin{array}{l}\text { H3) Concern for others will have a positive effect on perceived } \\
\text { usefulness and perceived ease of use }\end{array}$ & Accepted \\
\hline a) Concern for others & $\rightarrow$ & Perceived usefulness & Accepted \\
\hline b) Concern for others & $\rightarrow$ & Perceived ease of use & Accepted \\
\hline $\begin{array}{l}\text { H4) Extraversion / self-enhancement will have a positive effect on } \\
\text { perceived usefulness and perceived ease of use }\end{array}$ & Accepted \\
\hline $\begin{array}{l}\text { a) Extraversion / Self- } \\
\text { enhancement }\end{array}$ & $\rightarrow$ & Perceived usefulness & Accepted \\
\hline $\begin{array}{l}\text { b) Extraversion / Self- } \\
\text { enhancement }\end{array}$ & $\rightarrow$ & Perceived ease of use & Accepted \\
\hline H5) Perceived ease of use & $\rightarrow$ & Perceived usefulness & Accepted \\
\hline H6) Perceived usefulness & $\rightarrow$ & Behavioral intention & Accepted \\
\hline H7) Perceived ease of use & $\rightarrow$ & Behavioral intention & Rejected \\
\hline H8) Behavioral intention & $\rightarrow$ & Actual use of eWoM & Accepted \\
\hline
\end{tabular}




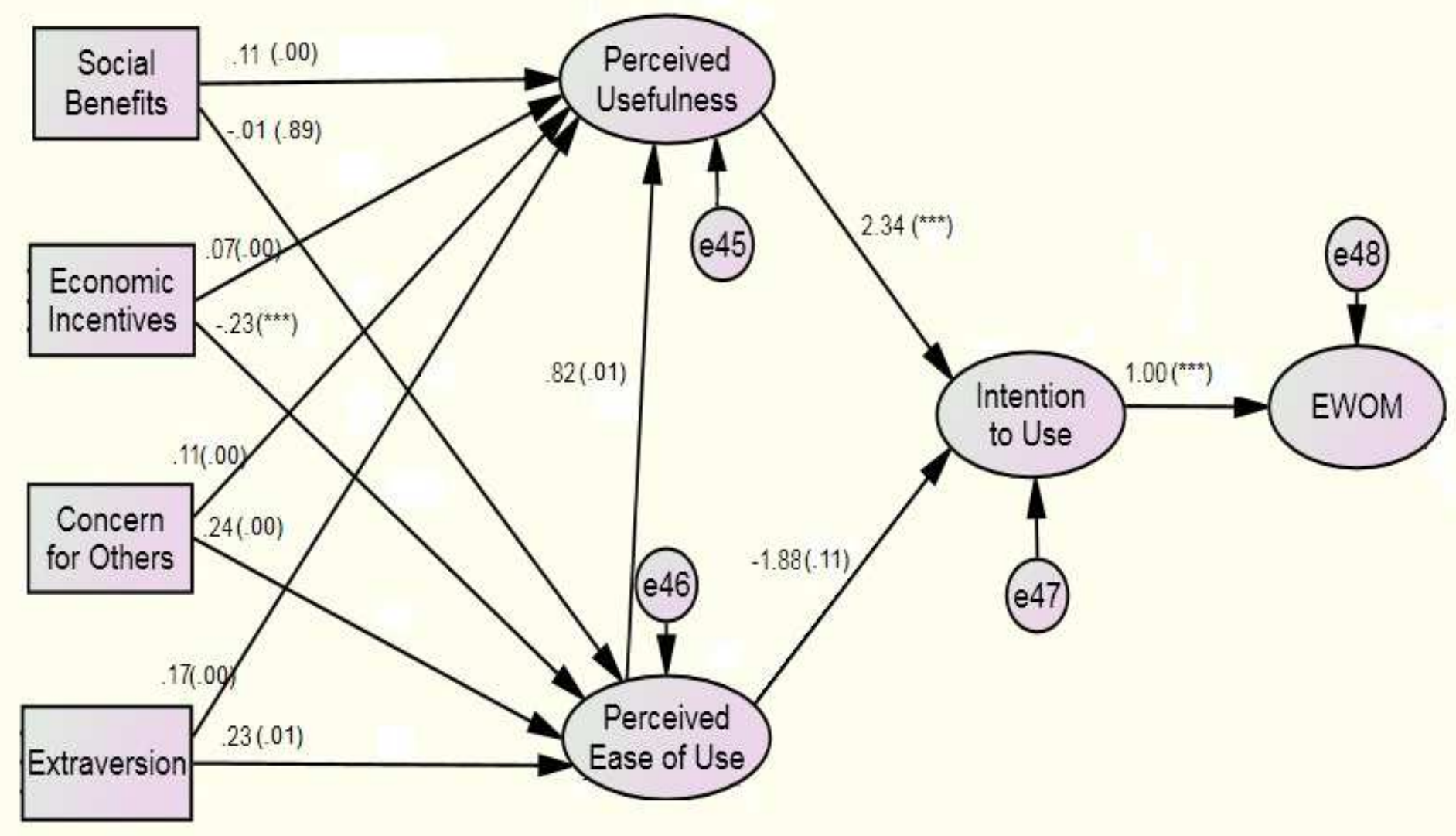

Figure 2: Standardized Estimates of the Research Model Using Structural Equation Modeling (SEM) 


\section{Mediation among Variables}

Table 10 shows direct, indirect, and total effect coefficients (and significance) of the model variables on the usage behavior of actual usage of eWOM on SNS variable.
Both direct and indirect coefficients initiated from the results of the path analysis (standardized coefficients). The researcher used the "Bootstrapping" method to obtain the significant levels of the indirect and total effects

\section{Table 10: Standard Direct, Indirect, Total Effects of Study Independent Variables on Intention}

\begin{tabular}{|l|l|l|l|}
\hline Variables & $\begin{array}{l}\text { Standardized } \\
\text { Direct effect }\end{array}$ & $\begin{array}{l}\text { Standardized } \\
\text { Indirect effect }\end{array}$ & $\begin{array}{l}\text { Standardized } \\
\text { Total effect }\end{array}$ \\
\hline $\begin{array}{l}\text { Social Benefits> } \\
\text { Actual use of eWOM }\end{array}$ & $.013(.890)$ & $.190(.001)$ & $.203(.001)$ \\
\hline $\begin{array}{l}\text { Economic } \\
\text { Incentives>Actual } \\
\text { use of eWOM }\end{array}$ & $.059(.320)$ & $.090(.002)$ & $.149(.001)$ \\
\hline $\begin{array}{l}\text { Concern for others> } \\
\text { Actual use of eWOM }\end{array}$ & $.186(.079)$ & $.105(.003)$ & $.291(.002)$ \\
\hline $\begin{array}{l}\text { Extraversion> } \\
\text { Actual use of eWOM }\end{array}$ & $.260(.043)$ & $.172(.001)$ & $.432(.001)$ \\
\hline
\end{tabular}

From table 10, social benefits of eWOM on SNS variable possesses a significant indirect and total effect on actual use of eWOM on SNS; however it has insignificant direct effect, through perceived usefulness, perceived ease of use and intention of eWOM on SNS as mediators. By definition; perceived usefulness, perceived ease of use and intention of eWOM on SNS are fully mediating variables between social benefits and actual use of eWOM on SNS.

The same goes for economic incentives and concern for others of eWOM on SNS variables as both of them have significant indirect and total effects on eWOM and an insignificant direct effect on actual use of eWOM. Thus, it can be concluded that perceived usefulness and perceived ease of use and intention of eWOM on SNS are fully mediating variables between concern for others and actual use of eWOM on SNS. Also, perceived usefulness and perceived ease of use and intention of eWOM on SNS are fully mediating variables between economic incentives and actual use of eWOM on SNS.

On the other hand, extraversion of eWOM on SNS has a significant direct, indirect, and total effect on actual use of eWOM on SNS. Thus, there is partial mediation of perceived usefulness and perceived ease of use and behavioral intention of eWOM on SNS between extraversion and actual use of eWOM on SNS.

\section{Discussion}

The first research hypothesis was to examine the effect of social benefits of eWOM on SNS on perceived usefulness of eWOM on SNS and perceived ease of use of eWOM on SNS. The hypothesis was partially accepted. On one hand, this study found a positive relationship between social benefits of eWOM on SNS and perceived usefulness of eWOM on SNS. The positive relationship of social benefits and perceived usefulness was supported by several previous researchers (Venkatesh and Davis, 2000; Venkatesh et al., 2003; Kwon and Wen, 2010; Lee, Xiong and Huc, 2011; Watjatrakul, 2013; Yap et al., 2012). On the other hand, social benefits of eWOM on SNS had an insignificant negative effect on perceived ease of use of eWOM on SNS. This finding is supported by some researchers and contradicted by others. Some of the previous researchers have proved a significant positive effect of social benefits on perceived ease of use (Venkatesh and Davis, 2000; Venkatesh et al., 2003; Kwon and Wen, 2010). Other researchers proved the opposite; that there is an insignificant relationship of social 
benefits on perceived ease of use (Kwon and Wen, 2010; Lin and Anol, 2008). This insignificant effect might be due to not taking into consideration a possible moderating effect of culture which has been studied by other researchers in this field such as the study conducted by Pookulangara and Koesler (2011). Thus, it might be useful to test the effect of culture as a moderating variable in future research. Another possible explanation is that social benefits might not be mediated by perceived ease of use as some researchers have proved a significant direct relationship between social benefits and behavioral intention to use social networks such as Parra-Lopez et al. (2011). Also, Kwon and Wen (2010) found that social benefits had insignificant effect on perceived ease of use and the researchers have explained this result by stating that: "Social identity will be seldom related to technical skill".

The insignificant effect of social benefits on perceived ease of use was also supported by Lin and Anol (2008) who studied the effect of social benefits on perceived usefulness and ease of use of using instant messaging and found this relationship to be insignificant. In the light of this finding, the current study recommends that future posts made by Egyptian marketers on SNS should be designed in a way that enhances consumer's identification with the SNS brand's community in order to meet their social need for group belonging and so that the consumer views himself or herself as a member of the brand's group. Consequently, consumers will actively participate more in SNS brand communities.

In this research, economic incentives of eWOM on SNS have a significant positive effect on usefulness of eWOM on SNS and this finding is supported by Roumani et al. (2014). However, economic incentives of eWOM on SNS had a significant negative effect on perceived ease of use of eWOM on SNS. Therefore, the second hypothesis of this study is partially accepted. In general, the economic incentives variable was studied in the context of eWOM, however very few researchers have examined the effect of economic incentive on perceived usefulness and perceived ease of use of
eWOM behavior. The negative relationship between economic incentives and perceived ease of use is illogic but it might be due to the absence of some moderating variable which might reverse the direction of the relationship. A possible moderator might be the relative importance of the economic incentive to the respondents. In other words, if the economic incentive is high but is of no relative importance to the respondent, then the perceived ease of use will decrease. In the light of Parra-Lopez et al.'s (2011) study; in which economic incentives had a positive direct effect on intentions to use social media; it might be valid that the relationship between economic incentives and intention to use eWOM on SNS is not mediated by perceived ease of use. This result could also be due to the users' unwillingness to declare whether they accept incentives in return for their eWOM contributions or not. Thus, according to this finding, Egyptian marketers are advised to design SNS posts which include economic incentives such as monetary rewards.

Concern for others of eWOM on SNS had a significant positive effect on perceived usefulness eWOM on SNS. This is supported by Kwon and Wen (2010) as they also found a significant positive relationship between the altruistic behavior of helping others and perceived usefulness of social network usage behavior. Also in the current study, concern for others eWOM on SNS had a significant positive effect on perceived ease of use of eWOM on SNS. This finding is supported by Parra-Lopez (2011). But on the contrary Kwon and Wen (2010) could not prove any positive significant relationship between concern for others and perceived ease of use. According to Cheung and Lee (2012); "Enjoyment of helping others is crucial in affecting consumers' eWOM intention. Intentions to write about experiences demonstrate enjoyment of helping others. Consumers can benefit other community members through helping them with their purchasing decisions. Specifically, this act can save others from having negative experiences." Therefore, it is recommended to design SNS posts in such a way that increases consumers' concern for others. 
Results demonstrated that extraversion/ self enhancement of eWOM on SNS had a significant positive effect on perceived usefulness of eWOM on SNS as well as perceived ease of use of eWOM on SNS. The positive relationship between extraversion and TAM beliefs is supported by the findings of Svendsen et al. (2013), their results indicate that personality influences behavioral intention both directly and indirectly and that the relationship is mediated through the TAM beliefs (i.e. perceived usefulness and perceived ease of use). Accordingly, Egyptian marketers are advised to design posts on SNS that boost their consumers' extraversion and enhances their self images for instance as experienced and clever shoppers.

TAM postulates that perceived ease of use has a positive direct effect on perceived usefulness (Davis, 1989), and the current study also confirms this positive relationship within the context of eWOM on SNS. This finding is in accordance with many previous research (Lee et al., 2011; Lee, Kim and Kim, 2012; Kwon and Wen, 2010; Pookulangara and Koesler, 2011).

Regarding the effect of perceived usefulness of eWOM on SNS on the behavioral intention to use eWOM on SNS, a significant positive effect was found. This finding is in agreement with literature studies (Kwon and Wen, 2010; Pookulangara and Koesler, 2011; Lin and Lu, 2011; Shin, 2008; Lee et al, 2011; AlGahtani, 2011). It is relevant to note that while some researchers have examined the direct effect of users' beliefs variables (i.e. perceived usefulness and perceived ease of use) on behavioral intention, others have assumed a mediating effect of attitude between them. However, the current study excluded the effect of attitude because according to Davis (1989); the attitude variable was found to have a weak effect on behavioral intention and that users' beliefs had a stronger direct effect on intention so it was better to exclude it from the model. This result indicates that the usefulness of SNS posts increases SNS users' intention to engage more in eWOM. Thus, Egyptian marketers are advised to attempt to increase the perceived usefulness of their posts on SNS.
The current research failed to prove the existence of significant positive relationship between perceived ease of use of eWOM on SNS and behavioral intention to use eWOM on SNS. To the contrary, an insignificant negative relationship between perceived ease of use of eWOM on SNS and behavioral intention to use eWOM on SNS was found. This finding is unfortunately against some of the literature studies (Kwon and Wen, 2010; Al-Gahtani, 2011). However, this finding might be attributed to one of the main disadvantages of the TAM which is the debatable role of perceived ease of use in the model. On one hand, some studies show that perceived ease of use has a direct and equal or a stronger effect than perceived usefulness on technology adoption. On the other hand, perceived ease of use had a small effect on intentions that subsided over time. Therefore, the implications for future research as pointed by Davis et al. (1989) were to test the generality of a perceived usefulness- perceived ease of use trade-off, and to assess the impact of external variables on these internal behavioral determinants (Yousafzai et al., 2007). Also, $\mathrm{Wu}$ and Wang (2005) confirm that one of the limitations to the TAM is that the perceived ease of use variable is less likely to be a determinant of attitude and usage intention according to studies of mobile commerce and online banking. It is relevant to note that some researchers have not considered any relationship between these two variables; for instance, Lin and Lu (2011) as well as Li, Chau, and Lou (2005) did not include perceived ease of use in their models though they were built based on TAM relationships. While other researchers proved a moderating effect of culture between perceived ease of use and intention such as Pookulangara and Koesler (2011). According to Yousafzai et al. (2007), the effect of culture can exert an effect on the predictive capacity of TAM since culture has a significant positive influence on TAM through perceived ease of use. However, the role of the research variable (perceived ease of use of eWOM on SNS) cannot be neglected in the current research model because it affects perceived usefulness of eWOM on SNS positively. Thus, it influences the behavioral intention to use eWOM on SNS indirectly through perceived usefulness of eWOM on SNS. 
A significant strong positive effect of behavioral intention to use eWOM on SNS was found on the usage behavior of eWOM on SNS in this study. This positive relationship between behavioral intention and actual use is in accordance with most studies in literature (Kwon and Wen, 2010; Venkatesh and Davis, 2000; Venkatesh et al., 2003). However, it is relevant to note that the effect of intention on usage was not studied much in literature as researchers focused more on studying the effect of variables on behavioral intention without extending their research into their actual usage variable. This might be considered as a contribution of the current study.

Finally, the current study offers some insights for Egyptian marketers who wish to improve their practices over SNS. According to the current study, the types of products which have the most attention by Egyptian Facebook users are; news and published media products (29.9\%) followed by fashion products (15.9\%) followed by electronic products (12.5\%). Therefore, marketers of these products should pay more attention to their marketing campaigns over SNS; for instance they could use the suggested factors affecting eWOM on SNS (social benefits, economic incentives, concern for others, extraversion and perceived usefulness) in designing their posts on SNS. Also, according to this study, marketers should focus their efforts towards age segments 18-24 (41.4\%) and 25-34 (35\%) because they account for the majority of Egyptian Facebook users. Marketers are also advised to focus more on highly educated SNS users; as graduate users accounted $61.6 \%$ of the study sample followed by post graduate users (31.2\%). In addition to that, the current study advises marketers to segment SNS users based on the factors affecting perceived usefulness of eWOM on SNS such as social benefits, economic incentives, concern for others and extraversion/ self enhancement.

\section{Conclusion and Recommendations}

There are a number of suggestions for future research concerning the factors affecting eWOM on SNS. Similar to other studies, this study has some limitations. The main limitation of the current study and some suggestions for further researchers are summarized as follow;

- In the current study, the researcher focused on users' characteristics according to the findings of Hennig-thurau et al. (2004), but there are more variables to be examined such as message characteristics and system characteristics. Also, the researcher examined eWOM from the receivers' perspective and the response. Other perspectives need to be examined which are; the communicator and the stimulus (Cheung and Lee, 2012).

- The researcher recommends the application of other existing models in the context of eWOM on SNS in Egypt such as the TPB, TRA, TAM2, TAM3, Motivation theory, Uses and gratification theory, etc. Since all of these models have already been applied outside Egypt according to the researcher's knowledge, then a comparison among these models could be made.

- The effect of culture could be taken into consideration in future research. The moderating effect of culture, level of expertise in using SNS as well as other variables are advised to be tested in future studies.

- Perceived enjoyment could be taken into consideration also as one of the potential factors that might be affecting eWOM on SNS.

- The factors affecting perceived ease of use could be reexamined because the current study failed to fully explain it.

- The effectiveness of eWOM behavior on SNS in Egypt needs to be investigated. The research on SNS in Egypt is still in its infancy. 
- For future research work, it is suggested that future studies would consider additional product categories in order to compare between their results.

- A replication of the same study could be made to other geographic regions in Egypt. This would serve the purpose of generalizability;

\section{References}

1. Abdelsalam, H. M., Reddick, C. G., Gamal, S., and Al-shaar, A. (2013) 'Social media in Egyptian government websites: Presence, usage, and effectiveness,' Government Information Quarterly, 30 (4), 406-416.

2. Ajzen, I. (1991) 'The Theory of Planned Behavior,' Organization Behavior and Human Decision Processes," 50, 179-211.

3. Al-Gahtani, S. (2011), 'Modeling the Electronic Transactions Acceptance Using an Extended Technology Acceptance Model,' Journal of Applied Computing and Informatics, 9, 47-77.

4. Arab Social Media Report (2011), 'Civil Movements: The Impact of Facebook and Twitter,' Dubai School of Government, 1, (2), 1-29.

5. Boyd, D. M., and Ellison N. B. (2007), 'Social Network Sites: Definition, History, and Scholarship,' Journal of ComputerMediated Communication, 13 (1), Retrieved from

http://jcmc.indiana.edu/vol13/issue1/boy d.ellison.html

6. Casaló, L. V., Flavián, C., \& Guinalíu, M. (2010), 'Determinants of the Intention to Participate in Firm-Hosted Online Travel Communities and Effects on Consumer Behavioral Intentions,' Tourism Management, 31 (6), 898-911.

7. Chang, C. C., Hung, S. W., Cheng, M. J., and $\mathrm{Wu}, \mathrm{C}$. Y. (2014), 'Exploring the Intention to Continue Using Social Networking Sites: The Case of Facebook,' Technological Forecasting and Social Change. since the current study cannot be generalized due to sample size as well as geographic limitations.

\section{Acknowledgement}

S. S. Doma would like to thank Professor Fred Davis for his academic advice.

8. Cheung, C., and Lee, M. (2012), 'What Drives Consumers to Spread Electronic Word of Mouth in Online ConsumerOpinion Platforms,' Decision Support Systems, 53, 218-225.

9. Clemons, E. K. (2009), 'The Complex Problem of Monetizing Virtual Electronic Social Networks,' Decision Support Systems, $48,46-56$.

10. Davis, F. D. (1989), 'Perceived Usefulness, Perceived Ease of Use, and User Acceptance of Information Technology,' MIS Quarterly, 13 (3), 319-340.

11. Davis, F. D., Bagozzi, R. B., and Warshaw, P. R. (1989), 'User Acceptance of Computer Technology: A Comparison of Two Theoretical Models,' Management Science, 30 (8), 982-1003.

12. Dellarocas, C. (2003), 'The Digitization of Word of Mouth: Promise and Challenges of Online Feedback Mechanisms," Management science, 49 (10), 1407-1424.

13. Engel, J. E., Kegerreis, R. J., and Blackwell, R. D. (1969), 'Word-of-Mouth Communications by the Innovator,' Journal of Marketing, 33, 15-19.

14. Engel, J. F., Blackwell, R. D., and Miniard, P.W. (1993). Consumer Behavior (8th ed.). Fort Worth: Dryden Press, Chicago.

15. Feick, L. F. and Price L. (1987), 'The Market Maven: A Diffuser of Marketplace Information,' Journal of Marketing, 51 (1), 83-97.

16. Flynn, L. R., Goldsmith, R. E. and Eastman, J. K. (1996), 'Opinion Leaders and Opinion Seekers: Two New Measurement Scales,' Journal of the Academy of Marketing Science, 24 (2), 137-147. 
17. Goldsmith, R. E. (2006). Electronic Word-of-Mouth. In M. Khosrow-Pour (ed.), Encyclopedia of E-Commerce, EGovernment, and Mobile Commerce. Hershey, PA.

18. Goldsmith, R. E., and Clark, R. A. (2008), 'An Analysis of Factors Affecting Fashion Opinion Leadership and Fashion Opinion Seeking,' Journal of Fashion Marketing and Management, 12 (3), 308322.

19. Goldsmith, R. E., and Horowitz, D. (2006), 'Measuring Motivations for Online Opinion Seeking,' Journal of Interactive Advertising, 6 (2), Retrieved from http://www.jiad.org/article76.

20. Hair, J., Anderson, R., Tatham, R., and Black W. (1998), Multivariate Data Analysis. Prentice Hall, Upper Saddle River, New Jersey.

21. Hair, J., Bush, R., and Ortinau, D. (2003). Marketing Research within a Changing Information Environment. McGraw Hill, Pennsylvania.

22. Hennig-Thurau, T., Gwinner, K. P., Walsh, G., and Gremler, D. (2004), 'Electronic Word-of-Mouth via ConsumerOpinion Platforms: What Motivates Consumers to Articulate Themselves on The Internet?,' Journal of Interactive Marketing, 18 (1), 38-52.

23. Hoffman, Donna L. and Thomas P. Novak (1996), 'Marketing in Hypermedia Computer-Mediated Environments: Conceptual Foundations,' Journal of Marketing, 60 (7), 50-68.

24. Hung, K. H., and Li, S. Y. (2007), 'The Influence of eWOM on Virtual Consumer Communities: Social Capital, Consumer Learning, and Behavioral Outcomes,' Journal of Advertising Research, 47 (4), 485495.

25. Jansen, B., Zhang, M., Sobel, K., and Chowdury (2009), 'Twitter Power: Tweets as Electronic Word of Mouth,' Journal of the American Society for Information Science and Technology, 60 (11), 2169-2188.

26. Jeong, E. H. and Jang E. H. (2011), 'Restaurant Experiences Triggering
Positive Electronic Word-of-Mouth (eWOM) Motivations,' International Journal of Hospitality Management, 30, 356-366.

27. Jin, C. (2013), 'The Perspective of a Revised TRAM on Social Capital Building: The Case of Facebook Usage,' Information and Management, 50 (4), 162-168.

28. Jiyoung, C. (2009), 'Shopping on Social Networking Web Sites: Attitudes toward Real versus Virtual Items,' Journal of Interactive Advertising, 10 (1), 77-93.

29. Kim, W., Jeong, O.R., and Lee, S.W. (2010), 'On Social Web sites,' Journal of Information Systems, 35, 215-236.

30. King, C. W., and Summers, J. O. (1970), 'Overlap of Opinion Leadership Across Consumer Product Categories,' Journal of Marketing Research, 7, 43-50.

31. Krejcie, R. V., and Morgan, D. W. (1970). Determining Sample Size for Research Activities. National Emergency Training Center, Emmetsburg.

32. Kwon, O., and Wen, Y. (2010), 'An Empirical Study of the Factors Affecting Social Network Service Use,' Journal of Computers in Human Behavior, 26, 254263.

33. Lee, D., Kim, H. S., and Kim, J. K. (2012), 'The Role of Self-Construal in Consumers' Electronic Word of Mouth (eWOM) in Social Networking Sites: A Social Cognitive Approach,' Computers in Human Behavior, 28 (3), 1054-1062.

34. Lee, K.O. M., Shi, N., Cheung, C. M. K., Lim, K. H., and Sia, C. L. (2011), 'Consumer's Decision to Shop Online: The Moderating Role of Positive Informational Social Influence,' Journal of Information and Management, 48 (6), 185-19.

35. Lee, W., Xiong, L., Huc, C. (2011), 'The Effect of Facebook Users' Arousal and Valence on Intention to go to the Festival: Applying an Extension of the Technology Acceptance Model,' International Journal of Hospitality Management, In Press, doi:10.1016/j.ijhm.2011.09.018.

36. Lenhart, A., and Madden, M. (2007), 'Social Networking Websites and Teens: An 
Overview,' $\quad$ Retrieved from http://www.pewinternet.org/Reports/200 7/Social-Networking-Websites-and-

Teens.aspx.

37. Lenhart, A., Purcell, K., Smith, A. and Zickuhr, K. (2010), 'Social Media and Mobile Internet Use among Teens and Young Adults,' Pew Research Center's Internet and American Life Project, Retrieved from http://www.pewinternet.org/Reports/201 0/Social-Media-and-Young-Adults.aspx.

38. Li, D., Chau, P. Y. and Lou, H. (2005), 'Understanding Individual Adoption of Instant Messaging: An Empirical Investigation,' Journal of the Association for Information Systems, 6 (4), 102-129.

39. Lin K. Y., and Lu, H. P. (2011), 'Why people use social networking sites: An Empirical Study Integrating Network Externalities and Motivation Theory,' Journal of Computers in Human Behavior 27, 1152-116.

40. Lin, C. P., and Anol, B. (2008), 'Learning Online Social Support: An Investigation of Network Information Technology based on UTAUT,' Cyber Psychology and behavior, 11(3), 268-272.

41. Norman, A. T., and Russell, C. A. (2006), 'The Pass-Along Effect: Investigating Wordof-Mouth Effects on Online Survey procedures,' Journal of Computer-Mediated Communication, 11 (4), Retrieved from http://jcmc.indiana.edu/vol11/issue4/nor man.html.

42. Park D.H. and Kim S. (2008), 'The Effects of Consumer Knowledge on Message Processing of Electronic Word-ofMouth via Online Consumer Reviews,' Electronic Commerce Research and Applications, 7, 399-410.

43. Park, C., and Lee, T. M. (2009), 'Antecedents of Online Reviews' Usage and Purchase Influence: an Empirical Comparison of US and Korean Consumers,' Journal of Interactive Marketing, 23 (4), 332-340.

44. Parra-Lopez, E. Bulchand-Gidumal, J., Gutiérrez-Tano, D., and Diaz-Armas, R. (2011), 'Intentions to Use Social Media in
Organizing and Taking Vacation Trips,' Journal of Computers in Human Behavior, $27,640-654$.

45. Patterson, A. (2011), 'Social Networkers of the World, Unite and Take Over: A Meta-Introspective Perspective on the Facebook Brand,' Journal of Business Research, Article In Press.

46. Picazo-Vela, S., Chou, S. Y., Melcher, A. J., and Pearson, J. M. (2010), 'Why Provide an Online Review? An Extended Theory of Planned Behavior and the Role of Big-Five Personality Traits,' Computers in Human Behavior, 26, 685-696.

47. Pookulangara, S. and Koesler, K. (2011), 'Cultural Influence on Consumers' Usage of Social Networks and its' Impact on Online Purchase Intentions," Journal of Retailing and Consumer Services, 18, 348354.

48. Roumani, Y., Nwankpa, J. K., and Roumani, Y. F. (2014), 'The Impact of Incentives on the Intention to Try a New Technology,' Technology Analysis and Strategic Management, (ahead-of-print), 116.

49. Rong, J., Vu, H. K., Law, R., Li, G. (2011), 'A Behavioral Analysis of Web Sharers and Browsers in Hong Kong Using Targeted Association Rule Mining,' Journal of Tourism Management, 1-10.

50. Sekaran, U., and Bougie, R. (2003). Research Methodology for Business.

51. Social Bakers (2014), 'Egypt Facebook Statistics,' Retrieved from: http://www.socialbakers.com/facebookstatistics/egypt

52. Sun, T., Youn, S. Wu, G. and Kuntaraporn, M. (2006), 'Online Word-ofMouth (Or Mouse): An Exploration of Its Antecedents and Consequences,' Journal of Computer-Mediated Communication, 11 (4), article 11, Retrieved from http://jcmc.indiana.edu/vol11/issue4/sun. html

53. Sundaram, D. S., Mitra, K., and Webster, C. (1998), 'Word of Mouth Communications: A Motivational Analysis,' Advances in Consumer Research, 25, 527531. 
54. Svendsen, G. B., Johnsen, J. A. K., AlmåsSørensen, L., and Vittersø, J. (2013), 'Personality and Technology Acceptance: The Influence of Personality Factors on the Core Constructs of the Technology Acceptance Model,' Behaviour and Information Technology, 32 (4), 323-334.

55. Venkatesh, V. (2000), 'Determinants of Perceived Ease of Use: Integrating Control, Intrinsic Motivation, and Emotion into the Technology Acceptance Model,' Information System Research, 11 (4), 342365.

56. Venkatesh, V., and Davis, F. D. (2000), 'A Theoretical Extension of the Technology Acceptance Model: Four Longitudinal Field Studies,' Management Science, 46 (2), 186204.

57. Venkatesh, V. Morris, M. G., Davis, G. B., and Davis, F. D. (2003), 'User Acceptance of Information Technology: Toward a Unified View,' MIS Quarterly, 27 (3), 425-478.

58. Watjatrakul, B. (2013), 'Intention to Use a Free Voluntary Service: The Effects of
Social Influence, Knowledge and Perceptions,'Journal of Systems and Information Technology, 15 (2), 202-220.

59. Wu, J. H., and Wang, S. C. (2005), 'What Drives Mobile Commerce?: An Empirical Evaluation of the Revised Technology Acceptance Model," Information and Management, 42 (5), 719-729.

60. Yang, C. C., and Brown, B. B. (2013), 'Motives for Using Facebook, Patterns of Facebook Activities, and Late Adolescents' Social Adjustment to College,'Journal of Youth and Adolescence, 42 (3), 403-416.

61. Yap K. P., Soetarto, B., and Sweeney, J. C. (2013), 'The Relationship between Electronic Word-of-Mouth Motivations and Message Characteristics: The Sender's Perspective,' Australasian Marketing Journal, 21, 66-74.

62. Yousafzai, S. Y., Foxall, G. R., and Pallister, J. G. (2007), 'Technology Acceptance: A Meta-Analysis of the TAM: Part 1,' Journal of Modelling in Management, $2 \quad$ (3), 251-280. 


\section{Appendix}

Questionnaire

Part One: Please answer the following questions:

\section{How many times do you use Facebook?}

$\square$ More than twice/ day

$\square$ Twice / day

$\square$ Once / day

$\square$ Once / week

$\square$ Once / month

\section{Which of the following products enjoys the majority of your comments on Facebook?}

Please choose Only One product or service since the rest of your answers to questions in this questionnaire will be based on this choice.

Electronic products

$\square$ Telecommunication products

$\square$ News and published media

$\square$ TV channels or programs

$\square$ Movies or Music

Fashion products

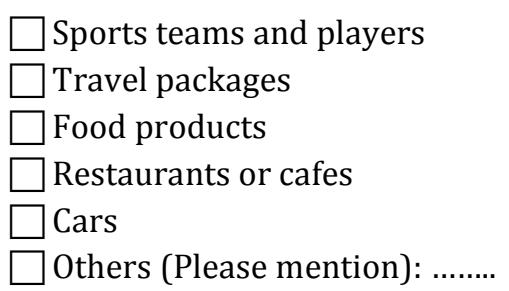

Part Two: Please provide your opinion accurately. On a scale from 1 to 5, please mark a circle around the number which represents the extent to which you agree or disagree with each of the following statements ; where 5 indicates "strongly agree" and 1 indicates "strongly disagree" as shown in the scale:

\begin{tabular}{|c|c|c|c|c|c|}
\hline \multirow{3}{*}{ Scale } & $\begin{array}{c}\text { Strongly } \\
\text { Disagree }\end{array}$ & Disagree & Neutral & Agree & $\begin{array}{c}\text { Strongly } \\
\text { Agree }\end{array}$ \\
\cline { 2 - 6 } & 1 & 2 & 3 & 4 & 5 \\
\hline
\end{tabular}

\begin{tabular}{|c|c|c|c|c|c|}
\hline $\begin{array}{l}\text { I write comments on Facebook because I want to give } \\
\text { others the opportunity to buy the right product. }\end{array}$ & 1 & 2 & 3 & 4 & 5 \\
\hline $\begin{array}{l}\text { Using Facebook enables me acquire more information or } \\
\text { meet more people. }\end{array}$ & 1 & 2 & 3 & 4 & 5 \\
\hline $\begin{array}{l}\text { I like forwarding interesting Facebook posts about products } \\
\text { from one group of my friends to another. }\end{array}$ & 1 & 2 & 3 & 4 & 5 \\
\hline $\begin{array}{l}\text { I feel more comfortable buying or downloading products } \\
\text { when I have gotten other people's opinions on it over } \\
\text { Facebook. }\end{array}$ & 1 & 2 & 3 & 4 & 5 \\
\hline $\begin{array}{l}\text { I write comments on Facebook because of the incentives I } \\
\text { receive. }\end{array}$ & 1 & 2 & 3 & 4 & 5 \\
\hline $\begin{array}{l}\text { My friends tend to ask my advice about products over } \\
\text { Facebook. }\end{array}$ & 1 & 2 & 3 & 4 & 5 \\
\hline $\begin{array}{l}\text { I write comments on Facebook because I want to warn } \\
\text { others of bad products. }\end{array}$ & 1 & 2 & 3 & 4 & 5 \\
\hline $\begin{array}{l}\text { Using Facebook would improve my efficiency in sharing } \\
\text { information and connecting with others. }\end{array}$ & 1 & 2 & 3 & 4 & 5 \\
\hline $\begin{array}{l}\text { I tend to seek out or search for others' opinions or } \\
\text { comments on Facebook regarding what products I might } \\
\text { buy. }\end{array}$ & 1 & 2 & 3 & 4 & 5 \\
\hline
\end{tabular}




\begin{tabular}{|c|c|c|c|c|c|}
\hline $\begin{array}{l}\text { When I receive a forwarded Facebook posts about a friend's } \\
\text { favorite product, I will forward it to her/him. }\end{array}$ & 1 & 2 & 3 & 4 & 5 \\
\hline $\begin{array}{l}\text { Given that I have access to Facebook, I predict that I would } \\
\text { use it. }\end{array}$ & 1 & 2 & 3 & 4 & 5 \\
\hline $\begin{array}{l}\text { Compared with my circle of friends, I am more likely to be } \\
\text { asked about products over Facebook. }\end{array}$ & 1 & 2 & 3 & 4 & 5 \\
\hline Facebook is a useful service for communication. & 1 & 2 & 3 & 4 & 5 \\
\hline $\begin{array}{l}\text { I like to seek out negative reviews about some products on } \\
\text { Facebook before I make a decision. }\end{array}$ & 1 & 2 & 3 & 4 & 5 \\
\hline $\begin{array}{l}\text { I write comments on Facebook because I meet nice people } \\
\text { this way. }\end{array}$ & 1 & 2 & 3 & 4 & 5 \\
\hline $\begin{array}{l}\text { I write comments on Facebook because my contributions } \\
\text { show others that I am a clever customer. }\end{array}$ & 1 & 2 & 3 & 4 & 5 \\
\hline $\begin{array}{l}\text { I would find it easy to get Facebook to do what I want it to } \\
\text { do. }\end{array}$ & 1 & 2 & 3 & 4 & 5 \\
\hline $\begin{array}{l}\text { I like to forward my friends' Facebook posts containing } \\
\text { information or opinions about the products that I like. }\end{array}$ & 1 & 2 & 3 & 4 & 5 \\
\hline $\begin{array}{l}\text { I tend to search for the latest online information on } \\
\text { products before I buy or download it. }\end{array}$ & 1 & 2 & 3 & 4 & 5 \\
\hline $\begin{array}{l}\text { During the past six months, I have told my friends about } \\
\text { products over Facebook. }\end{array}$ & 1 & 2 & 3 & 4 & 5 \\
\hline I tend to forward my friends positive reviews on products. & 1 & 2 & 3 & 4 & 5 \\
\hline $\begin{array}{l}\text { My friends think of me as a good source of information over } \\
\text { Facebook when it comes to obtaining new products. }\end{array}$ & 1 & 2 & 3 & 4 & 5 \\
\hline $\begin{array}{l}\text { I write comments on Facebook because I believe a chat } \\
\text { among like-minded people is a nice thing. }\end{array}$ & 1 & 2 & 3 & 4 & 5 \\
\hline $\begin{array}{l}\text { Over Facebook, I tend to seek the advice of my friends } \\
\text { regarding which products I should get. }\end{array}$ & 1 & 2 & 3 & 4 & 5 \\
\hline $\begin{array}{l}\text { Over Facebook, I tend to influence people's opinions about } \\
\text { some products. }\end{array}$ & 1 & 2 & 3 & 4 & 5 \\
\hline $\begin{array}{l}\text { I write comments on Facebook because this way I can } \\
\text { express my joy about a good buy. }\end{array}$ & 1 & 2 & 3 & 4 & 5 \\
\hline I tend to forward my friends negative reviews on products. & 1 & 2 & 3 & 4 & 5 \\
\hline Facebook is a useful service for interaction of members. & 1 & 2 & 3 & 4 & 5 \\
\hline $\begin{array}{l}\text { When I consider choosing products, I seek other people for } \\
\text { advice Facebook. }\end{array}$ & 1 & 2 & 3 & 4 & 5 \\
\hline Learning to operate Facebook would be easy for me. & 1 & 2 & 3 & 4 & 5 \\
\hline $\begin{array}{l}\text { I write comments on Facebook because I want to save } \\
\text { others from having the same negative experiences as me. }\end{array}$ & 1 & 2 & 3 & 4 & 5 \\
\hline $\begin{array}{l}\text { I tend to use the "Send this page to my friend" function on } \\
\text { Facebook when I find interesting products. }\end{array}$ & 1 & 2 & 3 & 4 & 5 \\
\hline $\begin{array}{l}\text { I write comments on Facebook because I feel good when I } \\
\text { can tell others about my buying successes. }\end{array}$ & 1 & 2 & 3 & 4 & 5 \\
\hline $\begin{array}{l}\text { I write comments on Facebook because I receive a reward } \\
\text { for the writing. }\end{array}$ & 1 & 2 & 3 & 4 & 5 \\
\hline $\begin{array}{l}\text { I tend to consult other people over Facebook to help me } \\
\text { choose the products I buy or download. }\end{array}$ & 1 & 2 & 3 & 4 & 5 \\
\hline I would find Facebook easy to use. & 1 & 2 & 3 & 4 & 5 \\
\hline $\begin{array}{l}\text { Via Facebook, I like to influence the types of products my } \\
\text { friends choose. }\end{array}$ & 1 & 2 & 3 & 4 & 5 \\
\hline $\begin{array}{l}\text { I write comments on Facebook because I can tell others } \\
\text { about a great experience. }\end{array}$ & 1 & 2 & 3 & 4 & 5 \\
\hline
\end{tabular}




\begin{tabular}{|c|c|c|c|c|c|}
\hline $\begin{array}{l}\text { I write comments on Facebook because it is fun to } \\
\text { communicate this way with other people in the community. }\end{array}$ & 1 & 2 & 3 & 4 & 5 \\
\hline $\begin{array}{l}\text { I am the first to try new products; therefore, many people } \\
\text { regard me as a leader in this area. }\end{array}$ & 1 & 2 & 3 & 4 & 5 \\
\hline $\begin{array}{l}\text { It would be easy for me to become skillful at using } \\
\text { Facebook. }\end{array}$ & 1 & 2 & 3 & 4 & 5 \\
\hline $\begin{array}{l}\text { I like to seek out positive reviews about some products on } \\
\text { Facebook before I make a decision. }\end{array}$ & 1 & 2 & 3 & 4 & 5 \\
\hline Assuming I have access to Facebook, I intend to use it. & 1 & 2 & 3 & 4 & 5 \\
\hline $\begin{array}{l}\text { I write comments on Facebook because I want to help } \\
\text { others with my own positive experiences. }\end{array}$ & 1 & 2 & 3 & 4 & 5 \\
\hline $\begin{array}{l}\text { I have the feeling that my friends regard me as a good } \\
\text { online source of advice about products. }\end{array}$ & 1 & 2 & 3 & 4 & 5 \\
\hline
\end{tabular}

Part Three: Kindly provide the following information:

Age:

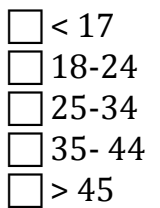

\section{Gender:}

Male

Female

\section{Educational Level:}

High school

$\square$ Graduate

$\square$ Post graduate

\section{Monthly Income:}

$\square>2000$ L.E
$\square 2000$ - 2999 L.E
$\square 3000$ - 3999 L.E
$\square 4000$ - 4999 L.E
$\square<5000$ L.E

